\title{
Concentrating Solar Power Advances in Geometric Optics, Materials and System Integration
}

\author{
Georgios E. Arnaoutakis *(D) and Dimitris Al. Katsaprakakis \\ Department of Mechanical Engineering, Hellenic Mediterranean University, Estavromenos, \\ 71004 Heraklion, Greece; dkatsap@hmu.gr \\ * Correspondence: arnaoutakis@hmu.gr
}

Citation: Arnaoutakis, G.E.;

Katsaprakakis, D.A. Concentrating

Solar Power Advances in Geometric

Optics, Materials and System

Integration. Energies 2021, 14, 6229.

https://doi.org/10.3390/

en14196229

Academic Editors: Ioan Sarbu and Carlo Roselli

Received: 14 August 2021

Accepted: 24 September 2021

Published: 30 September 2021

Publisher's Note: MDPI stays neutral with regard to jurisdictional claims in published maps and institutional affiliations.

Copyright: (c) 2021 by the authors. Licensee MDPI, Basel, Switzerland. This article is an open access article distributed under the terms and conditions of the Creative Commons Attribution (CC BY) license (https:/ / creativecommons.org/licenses/by/ $4.0 /)$.

\begin{abstract}
In this paper, the technological advances in concentrating solar power are reviewed. A comprehensive system approach within this scope is attempted to include advances of highly specialized developments in all aspects of the technology. Advances in geometric optics for enhancement in solar concentration and temperature are reviewed along with receiver configurations for efficient heat transfer. Advances in sensible and latent heat storage materials, as well as development in thermochemical processes, are also reviewed in conjunction with efficient system integration as well as alternative energy generation technologies. This comprehensive approach aims in highlighting promising concentrating solar power components for further development and wider solar energy utilization.
\end{abstract}

Keywords: concentrating solar power; geometrical optics; phase-change energy storage; renewable energy system integration

\section{Introduction}

Concentrating solar power (CSP) is one important option for utilization of the solar energy resource, whilst at the same time increasing the energy mix of existing power plants. Mature CSP technologies and incentives via feed-in tariffs offer rapid development of new power plants.

Solar thermal power plants are distinguished based on the types of solar collectors and receivers. For the solar radiation concentration, either linear or point focus collectors are employed. In linear focus collectors, optical concentration from 70 to 100 suns can lead to temperatures in the receiver up to $550{ }^{\circ} \mathrm{C}$. On the other hand, the optical concentration achieved in point focus collectors can reach 1000 suns, leading to working medium temperatures in the receiver higher than $1000{ }^{\circ} \mathrm{C}$. The most technically mature concentrating solar power technologies are:

- Parabolic trough collectors (PTCs);

- Linear Fresnel reflectors (LFRs);

- Parabolic dish collectors (PDCs);

- Solar power towers (SPTs).

The first two of the above listed technologies are linear focus systems, while the last two are point focus systems as shown in the schematic of Figure 1.

New advances in the CSP technology encouraged by legislation can promote higher penetration and faster replacement of fossil fuel plants. Significant advances have been reported in all aspects of the technology. An attempt to intuitively organize these advances will be followed in this review, according to the path solar energy via sunlight meets them in a solar power plant. Accordingly, this structure is: (1) optics for solar energy collection $\rightarrow$ (2) receivers for collection $\rightarrow$ (3) heat storage material. The vast literature in optics and receivers for collection of solar energy is distinguished between linear or two-dimensional and point focus or three-dimensional concentration. Moreover, heat 
storage materials depending on their heat content are organized in (1) sensible, (2) latent, and (3) thermochemical heat storage. There are several advances in storage materials below $100{ }^{\circ} \mathrm{C}$ in literature. However, due their limited application in utility scale plants they do not fit within the scope of this review and are excluded. Finally, a solar thermal power plant cannot be complete without optimized integration of its components as well as efficient and cost-effective scheduling. Levelized cost of electricity (LCOE) is used as the metric to enable comparison between promising technologies. LCOE is defined by the ratio of all costs to the energy produced during the lifetime of a power plant, normalized by a relevant discount rate.
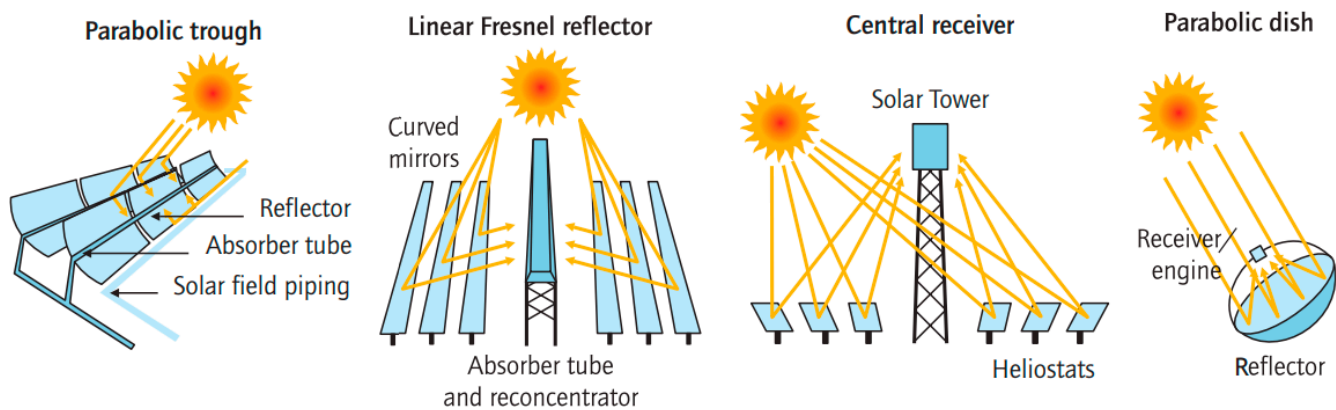

Figure 1. Concentrating geometries of the main solar power technologies in this review. Adapted with permission [1]; 2019, Elsevier.

\section{Linear Concentrating Solar Power Technologies}

\subsection{Parabolic Trough Collector}

Parabolic trough collectors (PTC) are the most commonly utilized types of concentrating solar collectors in solar thermal power plants. The system is composed of linear focus concentrating solar collectors. The collectors track the sun along the east-west axis, while the solar collectors are oriented to the north-south axis. Depending on the latitude of the location, east-west orientation can be used, for example to provide higher flux intensity. The collectors are rotated around the horizontal axis, tracing the sun's orbit on the horizon from the east to the west, i.e., the solar altitude.

In a typical parabolic trough solar thermal power plant, solar collectors are connected in series. The output of the required series in parallel are connected to reach the required thermal power production at the nominal operation point. The number of the in-series connected solar collectors at each line depend on the temperature of the heat transfer fluid (HTF) required to increase during circulation in the receiver. The receiver tubes between collector lines should be connected with flexible joints, to enable rotation during tracking. Additionally, the same joints should be able to treat linear thermal expansion of the receiver tubes. The efficiency of a PTC power plant, defined by the ratio of the produced electrical power and the incident irradiance, is at the range of $14-25 \%$ [2].

\subsection{Linear Fresnel Reflector}

Linear Fresnel reflectors (LFR) consist of planar or slightly curved reflectors, with their reflected surfaces made of glass, concentrating to one or more linear receivers, facing the reflectors. The receiver is placed along the focus of the Fresnel reflectors and, commonly consists of selectively coated metal tube equal to the receiver length. To minimize optical losses and increase solar concentration, a secondary reflector is installed above the receiver. The metal absorber can be also enclosed inside a glass tube, as in parabolic trough collectors, for further reduction of the heat losses from the absorber to the ambient. The LFR exhibits lower optical performance and thermal power production, however, these drawbacks are compensated by a lower set-up and maintenance cost.

The design of the Fresnel reflectors enables the construction of concentrating reflectors with high aperture and low focal length, leading to the reduction of the required material for the construction of the reflectors and the subsequent drop of the manufacturing and 
procurement cost. Additionally, in LFR systems, the solar radiation is concentrated by a number of Fresnel reflectors at the same receiver, unlike the parabolic collectors, where each collector is equipped with its own receiver.

The receiver in LFR systems is fixed, hence there is no need for flexible hydraulic joints. The type of the receiver depends on the working fluid for heat transfer. The receiver most commonly consists of parallel, black-coated absorber tubes, made of high-temperature metal alloys. This construction is used with water-steam mixture or molten salt as the working fluid. In cases of air, volumetric absorbers are employed, which use a highly porous ceramic structure to absorb the reflected solar radiation and heat the air flowing through them.

One of the losses in LFR systems is optical shading by neighboring reflectors. This can be treated by using techniques such as reflectors focusing on nearby receivers. With this approach, the density of the installed reflectors on the available land can increase, leading to a subsequent drop of the required occupied land.

Similar to the parabolic solar collectors, thermal energy is absorbed in the receiver by a working fluid, which can be a synthetic oil, a water-steam mixture or a molten salt. The most popular application is with the use of water-steam mixture. The water-steam mixture is heated up under pressure of $50-60$ bar and temperature $280{ }^{\circ} \mathrm{C}$ for the production of saturated or super-heated steam, which is led directly to the steam turbine.

A compact variation of this technology is the so-called compact LFR (CLFR) [3]. Contrary to the single receiver utilized in the LFR, in the CLFR implementation, there are different receivers placed above the reflectors' installation area. Hence, if the receivers are installed close enough to each other, each single reflector will have the option to focus between two alternative receivers for the concentration of the reflected solar radiation. This option constitutes the solution for the above-mentioned shading and blocking problem of the incident solar radiation from neighboring reflectors, offering the possibility for a denser siting of the Fresnel reflector lines. This is achieved by adjusting the inclination for every reflector differently, in combination with the neighboring lines, so each line is focused on different receivers, avoiding, thus, the solar radiation blocking or shading from neighboring reflector lines. The denser siting of the Fresnel reflectors imposes lower total length of the absorber tubes and higher installed power per occupied land unit, which, in turn, contributes to the reduction of the thermal energy losses to the ambient and the total set-up cost of the solar thermal power plant. More than 100 MWe of LFR systems have been installed worldwide to-date [4]. The main advantages of the LFR are lower set-up and operation costs compared to alternative concentrating solar power technologies, due to simplified installations and restricted maintenance requirements.

\subsection{Linear Receivers}

In commercial applications, the linear solar collectors are constructed with heavy and expensive thermoplastic glass of $4 \mathrm{~mm}$ thickness. Modern trends aim to the reduction of the collectors' weight with the introduction of new techniques and materials, such as the use of glazed aluminum, instead of glass. The receiver consisting of absorber tubes with a flowing working fluid is located at the focus of the parabola reflected incident solar radiation is concentrated. The receiver is designed and constructed in order to exhibit high incident solar radiation absorptance. For this purpose, the absorber tubes are manufactured from steel with black coating on the outer surface of absorptance exceeding $90 \%$, aiming to maximize the absorbed solar radiation and minimize the thermal losses via radiation to the environment. The steel tube is placed inside a protective glass tube. The space between the steel and the glass tubes is vacuum, aiming to the reduction of the thermal losses from the absorber tube to the ambient environment. Typical inner diameters for the steel and the glass tubes of the receiver can be $70 \mathrm{~mm}$ and $115 \mathrm{~mm}$, respectively. The glass tube outer surface is also covered with anti-reflective coating, to facilitate the transmittance of the incident solar radiation. 
A wide comparative study [5] of 32,000 dielectric-metal-dielectric (DMD) and transparent conductive oxide (TCO) coatings concluded to the ZnS-Ag-ZnS and indium tin oxide as the most efficient coatings. The comparison utilized a selectivity factor metric that considers the temperature, the solar concentration ratio and the radiative efficiency of the receiver. One of the findings was a higher selectivity efficiency at higher solar concentration. Moreover, the DMD coatings proved their higher solar transmission, whereas the TCO their efficient blackbody reflection. Application of TCO in parabolic trough receivers reported estimated heat loss reduction of approximately $15 \%$ at receiver temperature between $400-600{ }^{\circ} \mathrm{C}$ [6]. By optimizing the cut-off wavelength of the TCO the heat loss can be increased to higher than $40 \%$ for receiver temperatures of $600{ }^{\circ} \mathrm{C}$ [7].

In addition, the coatings should ideally be organic dirt-, dust-, abrasion- and corrosionfree. Among transition metal oxides, the photocatalytic properties of $\mathrm{TiO}_{2}$ have been extensively studied and its use as anti-soiling layer has been reported [8].

The HTF in the receiver, usually a synthetic oil with high thermal conductivity, through circulation in a closed loop, transfers the absorbed thermal energy from the solar collectors and to a series of heat exchangers, where the transferred heat is utilized for the production of superheated steam at temperatures of $370-400{ }^{\circ} \mathrm{C}$ and pressures of $90-100$ bar. The HTF inlet and outlet temperatures in and from the solar collector's field are in the range of $290{ }^{\circ} \mathrm{C}$ and $390^{\circ} \mathrm{C}$, respectively. The produced steam is then led to the steam turbines for the production of mechanical power. The synthetic oil usually used is a eutectic mixture of $73.5 \%$ diphenyl ether oxide and $26.5 \%$ diphenyl ether. The main operational problem with this material is its high solidification temperature, around $12{ }^{\circ} \mathrm{C}$, due to which an auxiliary heat source is required during periods of low ambient temperature and solar radiation availability. Additionally, the boiling point of this employed synthetic oil under pressure of 1.013 bar is $257^{\circ} \mathrm{C}$, hence, the synthetic oil inside the receiver's loop should be under pressure higher than the atmospheric, together with an inert gas to avoid evaporation at temperatures higher than its boiling point.

The maximum possible temperature of the synthetic oil at $400{ }^{\circ} \mathrm{C}$ sets an upper limit for the steam turbine efficiency. For this reason, there is currently extended research on the use of advanced heat transfer fluids in the receiver, such as molten salts, or on the direct use of steam. The use of molten salts enables the increase of the HTF temperature at the level of $560{ }^{\circ} \mathrm{C}$, leading to the subsequent increase of the power production process efficiency. While thermodynamic cycle efficiency up to $42 \%$ can be achieved with two-phase fluids, efficiency higher than $50 \%$ can be achieved with $700{ }^{\circ} \mathrm{C}$ temperatures HTF [9]. Direct steam generation (DSG) in the receiver has also been demonstrated [10]. This enabled the reduction of the system's set-up cost and the increase of the overall efficiency due to the elimination of the heat transfer losses in the oil-steam heat exchangers.

The solar thermal power plant can be equipped with a thermal storage plant, hence the thermal energy from the HTF primary loop can be alternatively disposed in the thermal tank, detailed in Section 4.

\subsection{Advances in Troughs}

Two-dimensional analysis has shown peak irradiance of $40 \mathrm{~kW} / \mathrm{m}^{2}$ [11] to reach temperatures higher than $400^{\circ} \mathrm{C}$ [12]. Depending on the defocalisation the optical efficiency can drop up to $50 \%$ by several $\mathrm{cm}$ [13].

Three-dimensional analysis exhibited the strong relation of the concentration and the rim angle of the parabola, with peak flux possible at $100 \mathrm{~kW} / \mathrm{m}^{2}$ [14]. Flux and photogrammetry measurements $[15,16]$ in a number of installed troughs exhibited local variations up to $80 \mathrm{~kW} / \mathrm{m}^{2}$, however, the cause of this variation was not discussed. Radiation losses higher than $150 \mathrm{~W} / \mathrm{m}^{2}$ reducing with the Re number were reported in similar analyses [17], caused by local temperature gradients up to $\Delta \mathrm{T}$ of $130 \mathrm{~K}$ [18] corresponding to flux gradients up to $370 \mathrm{~kW} / \mathrm{m}^{3}$ [19].

Lower temperature gradients of $25 \mathrm{~K}$ were reported [20] with molten salt HTF at irradiance up to $1250 \mathrm{~W} / \mathrm{m}^{2}$. 
To achieve this performance secondary reflectors are crucial. V-shaped [21] and varifocal reflectors [22] were reported in agreement with the non-imaging optics principles in the compound parabolic concentrator with demonstrated $63 \%$ optical and $40 \%$ thermal efficiency in a two-stage parabolic trough [23]. Secondary reflectors can also reduce extreme flux gradients. A comparative study of circumference, annulus aplanatic and seagullshaped reflectors, exhibited over $10{ }^{\circ} \mathrm{C}$ reduction of gradients [24]. Aplanatic optics can achieve nearly double the solar concentration of parabolic trough collectors with subsequent collector temperature up to $500{ }^{\circ} \mathrm{C}$ [25].

The application of radiation shields with thermal efficiency around $50 \%$ in place of reflectors, exhibited $28 \%$ reduced heat loss at $600{ }^{\circ} \mathrm{C}$ compared to conventional designs [26]. This corresponds to an increased energy production between 5-10\% [27]. Easier application of a radiation shield can be implemented by means of thermochromic layers which reported higher than $15 \%$ heat-loss reduction rates [28]. Reduced heat loss with radiation shield at the low flux region of the receiver can reduce the LCOE by more than $8 \%$ [29].

\subsection{Advances in Fresnel Reflectors}

In LFR systems, circular mirrors did not show any benefit over parabolic segments [30]. While the efficiency of the LFR is lower than the PTC with a design of lower LCOE, optimised north-south orientation did not exhibit much higher performance than the non-optimised east-west orientation [31].

The local concentration ratio of the CPC cavity peaked at 60 suns, however, falls off fast below an incidence angle of $90^{\circ}$ [32]. The concentration ratio of using a trapezoidal cavity exhibited peak concentration ratio of $40 \times$, dropping even faster at $40^{\circ}$ incidence which was reduced by using multiple tubes inside the cavity with reduced temperature gradient of $8 \mathrm{~K}$ [33].

A $12 \%$ relative gain can be obtained by independently arranging the reflectors [34]. It was shown that this gain is more strongly related to the optimization of the focal length than the position of the Fresnel reflectors.

\section{Point Focus Concentrating Solar Power Technologies}

\subsection{Parabolic Dish Collector}

The parabolic dish collector (PDC) utilizes one or multiple reflective, parabolic dishes for the solar radiation concentration on a focal point, where the receiver is placed. The concentrated solar radiation at the receiver is absorbed by the working fluid, a liquid or a gas, increasing its temperature up to 650 to $750{ }^{\circ} \mathrm{C}$. The heated working fluid is led to a thermal generator for the production of mechanical power. In case of parabolic dish collector, Stirling engines are most commonly used, exhibiting overall efficiencies at the range of $30 \%$. Alternatively, gas turbines of small size can be also used.

The diameter of a typical PDC employed in a solar thermal power plant can be from $5 \mathrm{~m}$ to $10 \mathrm{~m}$. The dish surface usually ranges from $40 \mathrm{~m}^{2}$ to $120 \mathrm{~m}^{2}$, although there are dishes constructed with surfaces up to $400 \mathrm{~m}^{2}$. The nominal electrical power output of a parabolic dish with $10 \mathrm{~m}$ diameter is at the range of $25 \mathrm{~kW}$. The PDC is composed by a number of circular or rectangular reflectors, assembled on a metallic truss. The reflective surfaces of the reflectors are constructed with glass or glazed metal. The receiver is placed on the extension of the focus of the parabolic dish, opposite the reflectors. Each PDC constitutes an individual power unity, with its own, separate thermal engine and electrical generator. This means that the parabolic dish collector is a modular technology, adapted easily to the requirements or the design conditions of each specific project, by simply adding or removing systems. This feature makes this particular technology quite attractive for decentralized power production and for remote, autonomous electrical systems.

A PDC is equipped with two-axes tracking, to trace the sun's orbit in the horizon and approach the maximum possible solar radiation concentration on the receiver. Given the requirement for a two-axes rotational system and the heavy construction of the dish engine, the tracking system exhibits considerably increased set-up cost. As mentioned just 
above, the receiver is placed opposite the reflectors. There are two main receiver types for parabolic dish systems, the Brayton and the Stirling receivers. The thermal energy rate with a Brayton receiver is constant. The working medium is air, under relatively low pressure. In most advanced Brayton receivers, the concept of volumetric absorbers is used, as in the case of the SPT receivers operating with air. A porous material is again used for the solar radiation absorption. The thermal energy is then transferred to the flowing air through the porous material.

The main advantages of PDC is their modular attribute and higher efficiency compared to alternative solar thermal technologies, mainly due to the utilization of Stirling engines operating at higher receiver temperatures. On the other hand, the relatively low power output of up to $25 \mathrm{kWe}$ for each dish system, low maturity and restricted experience from implemented projects, imposes reliability issues with regard to potential impacts on the stability of the electrical power production.

\subsection{Solar Power Tower}

Solar power tower (SPT) or central receiver systems (CRS) consist of individual, multiple tracking heliostats, with reflecting surface for each one from $1 \mathrm{~m}^{2}$ to $140 \mathrm{~m}^{2}$, placed around a central receiver, installed at the top of a tower. The heliostats are constructed with a flat or slightly curved glass surface. The reflected solar radiation from the heliostats is concentrated at the central receiver through appropriate orientation of the heliostats. For this reason, each heliostat is equipped with a two-axes tracking system, in order to follow the sun's position in the horizon. Rotary or linear drivers, or, in modern applications, hydraulic actuators, can be used for the tracking system. The central tower can be as high as $200 \mathrm{~m}$, depending on the size of the solar thermal power plant.

The siting of the heliostats with regard to the location of the power tower depends on the geographical latitude of the solar thermal power plant's installation site. The reflected solar radiation depends on the radiation's incident angle on the heliostat. According to solar geometry, the total incident solar radiation on flat surface is proportional to the cosine of the direct solar radiation incident angle $\theta i$ [35]. Consequently, for a solar thermal power plant installed in the north hemisphere, the $\cos \theta \mathrm{i}$ can approach 0.9 for the heliostats at the north side of a power tower, while for heliostats installed at the south side of the power tower, the $\cos \theta \mathrm{i}$ is considerably reduced. Hence, for plants installed at the north hemisphere, the solar field should be installed at the north side of the power tower, and vice versa. For solar plants installed close to the equator, the solar field should surround the power tower.

The concentrated solar radiation at the central receiver is transferred in the form of thermal energy towards the working fluid, similarly to parabolic trough systems. The absorbed thermal energy from the working fluid is then utilized for the production of steam, which, in turn, is exhausted in a steam turbine for the production of mechanical power. The working fluid can be a molten salt, air or water-steam mixture. There is also the option of thermal energy storage in a thermal storage tank. As in LFR systems, the receiver can consist of black-coated parallel absorber tubes, made of high-temperature metal alloys, in case the working fluid is water-steam mixture or molten salt, or volumetric absorbers with highly porous ceramic structure, in case the working fluid is air.

The optical concentration ratios with the SPT solar thermal power plants can range from 600 to 1000 suns, hence the temperature of the working medium and, eventually, the produced steam is higher than parabolic trough collectors. This necessitates the use of molten salts employed as the working medium in the receiver with higher temperatures compared to synthetic oil employed in parabolic collectors limited to $400{ }^{\circ} \mathrm{C}$, also limiting the exergy of the produced steam.

The temperature of the working fluid inside the commercial SPT absorbers can be up to $565{ }^{\circ} \mathrm{C}$, while values at the range of $1000{ }^{\circ} \mathrm{C}$ have been experimentally demonstrated [36]. Due to the high possible temperatures in the central receiver, the SPT power plants can be also combined, apart from steam turbines, with gas turbines and combined cycles. Indeed, 
a pressurized gas at temperatures close to $1000^{\circ} \mathrm{C}$, approaches the properties of the gases exhausted from a gas turbine. Moreover, if the employed gas turbines are integrated in the frame of a combined cycle, then the overall efficiency of the solar thermal power plant can reach values as high as 35\%, at nominal operation, and average annual efficiencies up to $25 \%$ [2].

SPT power plants, similar to parabolic trough collectors' plants, are integrated with conventional thermal power production unit and a thermal energy storage tank. Most commonly, the working medium employed in the thermal energy tank is molten salt.

The first commercial SPT plant was constructed in 2007 in Sanlucar la Mayor, close to Seville, Spain, with a nominal power of 11 MWe. The solar field consists of 624 heliostats which cover a total surface of $600,000 \mathrm{~m}^{2}$. The central power tower's height is $115 \mathrm{~m}$. The produced thermal energy is stored in the form of pressurized steam in thermal tanks, offering the ability for the power plant for up to two additional operation hours after the sunset. Additionally, there is a supplementary conventional natural gas heater. With the annual solar irradiation at $2100 \mathrm{kWh} / \mathrm{m}^{2}$, the specific SPT solar thermal power plant produces annually $24.3 \mathrm{GWh}$ of electricity, a figure which gives an annual capacity factor of $25 \%$. The overall, annual average efficiency is $17 \%$ [37].

The first SPT plant with molten salt employed as the working medium in the central receiver was constructed in 2011 at the location Fuentes de Andalucia, close to Seville, Spain again. The nominal power of this station is at 19.9 MWe. This station is equipped with thermal storage tanks with storage capacity that offers $15 \mathrm{~h}$ additional operation at nominal power without any solar radiation available. This feature practically enables continuous operation of the power plant during summer. The solar field consists of 2480 heliostats, with an effective surface of $300,000 \mathrm{~m}^{2}$ and total covered land of 1,420,000 $\mathrm{m}^{2}$. The plant's installation was completed in 2014. It has a nominal power of $392 \mathrm{MWe}$, with 173,500 heliostats, covering a total covered land of $16,000,000 \mathrm{~m}^{2}$. It consists of three separate power plants, with three individual power towers. The annual net final electricity production in 2015 reached $650 \mathrm{GWh}$, configuring, thus, an annual average capacity factor of 18.9\%. The annual average overall efficiency is estimated at $15.8 \%$. The total installed power of SPT plants globally is currently higher than 600 MWe [4].

\subsection{Optical Attenuation}

Sunlight reflected by several heliostats undergoes significant attenuation proportional to the slant range between heliostats and the tower receiver. As initially reported by [38], further fitted based on direct normal irradiance (DNI) [39] and extinction measurements [40] and extensively modeled by [41], attenuation is severe at low visibility conditions in rural areas with high aerosol optical depth.

Overestimation up to $17 \%$ and $20 \%$ was found [42] in annual energy output of $50 \mathrm{MWe}$ PTC and SPT plants, respectively. The discrepancies were shown to be due to overestimation of DNI and differences in the aerosol optical depth between ground and satellite measurements. Clear and hazy conditions fit into polynomial transmittance functions are commonly used [43]. Temporal models of the attenuation from data of ground station networks exhibited a $20 \%$ difference [44] in daily energy output from the polynomial models. Spectrally averaged aerosol optical depth was used [45] in agreement with broadband measurements [46].

Local measurements of aerosol optical depth are therefore important to accurately model the induced attenuation and its effect in the performance of SPT plants under development. The interested reader is directed towards reference [47] for a detailed review on the simulation and experimental methods in the determination of atmospheric extinction. The end flux imposed on the receiver is crucial in the design of a concentrating plant either to maximize collected energy of uniform or flattened distribution on receiver. Consequently, this can either be optimized by the heliostat field or the receiver as analyzed in the following sections. 


\subsection{Advances in Heliostat Layouts}

In addition to the atmospheric attenuation, the efficiency of the plant depends on the layout of the heliostats. The design of heliostat fields has been extensively modeled to minimize neighboring blocking and maximize optical efficiency. Analytical flux density distribution models can be used to model flat heliostats [14]. The Gaussian flux obtained by concentration of heliostats can be flattened by one- [48] and two-parameter aiming strategy [49]. An analysis of multiple heliostat focal points identified variation routines for a more uniform flux in the receiver [50], useful in the case of intentional dilution during the day. A review of a popular code for heliostat design can be found in [51]. While for 150 MW plants with $200-275 \mathrm{~m}$ tall towers, densely packed heliostats work better despite the occurred blocking [52]. The heliostat field need not have a physical pattern, in which case there can be cost advantages [53]. Extensive reviews of codes and tools for optimisation of heliostat fields were reported in [54-56].

Multi-tower solar arrays have been proposed [57] as well as optimum packing hexagonal heliostats [58], while a few percent improvement in field efficiency was reported by moving from square to circular heliostats [59]. The heliostat shape however should additionally consider wind loads and turbulence to drop the cost below $100 \$ / \mathrm{m}^{2}$ [60]. Furthermore, mirror soiling, erosion, aging and degradation [1] are further points for consideration affecting the annual performance of CSP plants. Methods integrating ray tracing and for on site characterization $[61,62]$ and misalignment have been reported [56]. Extensive characterization of additional mechanical attributes such as canting errors are needed to provide further insights for the development of the technology [63]. It can be expected that a concurrent approach of modeling and experiments can help develop better multi-component SPT systems.

The receiver of the SPT need not be at the top of the tower since sunlight reflected by the heliostats can be directed towards the ground by using beam-down geometries [64]. Additional concentration is likely required to concentrate reduce dilution [65]. The reflectors may consist of flat, ellipsoidal, hyperboloidal or paraboloidal reflectors [66] or may consist of multiple apertures [67]. In this case, the cost of the support for the reflector and additional complexity should compensate for the added benefit [68].

\subsection{Advances in Volume Receivers}

Stirling receivers can be distinguished in direct and indirect illumination receivers. In direct Stirling receivers, the heating pipelines of the Stirling motor are utilized for the concentrated solar radiation absorption. The concentrated solar radiation is transferred in the form of thermal energy to a high pressure gas such as helium or hydrogen, utilized for production of mechanical power in the Stirling engine. In this way, the efficiency of the power production process is maximized and the manufacturing cost of the Stirling engine is minimized, due to the elimination of heat exchangers and the use of a simpler engine. By using high pressure helium or hydrogen, the receiver can absorb high solar radiation rates reaching $75 \mathrm{~W} / \mathrm{cm}^{2}$. In indirect Stirling receivers, the thermal energy is transferred through a heat exchanger from the primary to the secondary loop, which is eventually utilized for power production. On March 2010 the first commercial parabolic dish system was installed in the city of Peoria, Arizona, U.S.A. It consists of 60 parabolic dish systems with a total nominal electrical power output of 1.5 MW.

Cavity receivers are primarily used in SPT and PDC systems so far. Solar concentration up to 3000 suns has been reported for dish with rim angle of $55^{\circ}$ [69]. The flux and intercept efficiency at the receiver of the PDC can be improved with secondary concentration optics. A three-dimensional CPC was improved by over $20 \%$ for receiver radii higher than $0.05 \mathrm{~m}$ [70]. The design has found application also as an SPT receiver [71]. The depth of the receiver should also be considered. Ellipsoidal receivers of $110 \mathrm{~mm}$ depth collect light more uniformly than $190 \mathrm{~mm}$ receivers [72]. Uniformity can be significant for receivers achieving local flux densities up to $90 \mathrm{~kW} / \mathrm{m}^{2}[73,74]$, while cavities of non-classical shapes can attain more uniform flux distributions [75]. Secondary concentration by means of plano-convex 
windows is also used to increase attainable in-cavity temperature [76]. The increased radiative heat-loss at high flux intensities can be reduced with air curtain designs. Recent analyses of air curtain surrounding receivers reported heat-loss reductions of more than $9 \%$ that is from 1.5 MW to $1.13 \mathrm{MW}$ [77].

SPT receivers for use with molten salt HTF consist of the body of the absorber facing the heliostats touch with tubular design for HTF flow [78]. The flux can be very high on the receiver, however may vary considerably due to the distribution of the tubes in the receiver [79]. Existing designs attain peak flux of $500 \mathrm{~kW} / \mathrm{m}^{2}$ at the center of the cavity [80] while after modification of the geometry this can be up to $700 \mathrm{~kW} / \mathrm{m}^{2}$ for temperatures up to $650{ }^{\circ} \mathrm{C}$ [81]. Naturally, the flux will fluctuate depending on passing clouds from $29 \mathrm{~kW} / \mathrm{m}^{2} / \mathrm{s}$ corresponding to power gradients of $1.7 \mathrm{MWth} / \mathrm{s}$ [82]. Dual receivers have also been reported $[83,84]$, however benefits should compensate for the added complexity.

Higher temperatures can be achieved in particle receivers. These can be free-falling or gravity-driven able to reach temperatures higher than $700{ }^{\circ} \mathrm{C}$, while obstructed flow, fluidized and rotating particle receivers were demonstrated for temperatures up to $900{ }^{\circ} \mathrm{C}$ [85]. The LCOE was estimated at \$10-13/MWh making it promising compared to alternatives such as batteries, pumped hydro, compressed air energy storage and flywheels [86]. For an overview of third generation receivers the reader is directed towards reference [87].

\section{Thermal Energy Storage}

Solar thermal power plants supply energy to a fluctuating power demand. Supplementary energy to this produced by solar radiation, is achieved with thermal energy storage. Thermal energy is stored in appropriate media to ensure a stable and constant power production, according to the predefined power production, regardless of solar radiation fluctuations. In this way, power production is prolonged during periods of insufficiency or absence of solar radiation. Thermal energy storage offers the option to the solar thermal power plant operator to shift the power production to periods with higher electricity selling prices improving the LCOE. The shift in power production may vary from minutes, to supply rapid shortages in the order of few MWh, to several hours between sunset and sunrise, depending on the energy demand. Accordingly, the stored thermal energy capacity in CSP plants may be up to several hundred MWh.

Thermal energy storage (TES) can be achieved with a wide variety of working media. The thermophysical properties of the media, such as melting point, latent and specific heat and thermal conductivity, define the operation of the system. Additionally, flammability, toxicity and low-cost availability in the market are key selection factors. Thermal and chemical stability, low expansion coefficient, low supercooling and low vapor pressure should be also considered [88]. Three major options currently exist in TES depending on the use of (a) sensible heat, (b) latent heat and (c) thermochemical reactions. Sensible and latent heat storage systems are currently utilized in thermal storage processes, including solar thermal power plants, while thermochemical heat storage systems are in the development stage. These are analyzed in the following subsections.

\subsection{Sensible Energy Storage}

Thermal energy storage in the form of sensible heat is based on the specific heat capacity of the working medium and its temperature rise during the thermal energy transfer process. The stored thermal energy is proportional to the mass of the working medium with specific heat capacity at the operating temperature gradient.

Sensible heat storage is usually executed with cheap and widely available materials, as well as more technologically mature. They are widely used in solar thermal power plants in Spain and the U.S. On the other hand, the major drawback of sensible heat storage is the relatively low energy density, which ranges between $60 \mathrm{kWh}$ th $/ \mathrm{m}^{3}$ for sand (storage temperatures range $200-300{ }^{\circ} \mathrm{C}$ ), rock, mineral oil and $150 \mathrm{kWh}$ th $/ \mathrm{m}^{3}$ for cast iron (storage temperature range $200-400^{\circ} \mathrm{C}$ ). This restricted energy density imposes the construction of storage units particularly large. Compared to latent heat thermal storage, the specific 
heat capacity of the materials used for sensible heat storage is 50-100 times smaller and, consequently, the available sensible thermal storage potential is proportionally reduced.

Water/steam: Water exhibits very attractive features with regard to its use as thermal storage material, such as high specific heat $(4.184 \mathrm{~kJ} / \mathrm{kg} . \mathrm{K})$, high availability and low cost, non-flammability and non-toxicity. On the other hand, the major drawbacks of water as a TES material are high vapor pressure and corrosion. Apart from liquid phase, water can be also used as ice, for cooling applications, and steam. For solar thermal power plants, water is used in the form of steam, most commonly exploited in direct steam generation (DSG) systems [4].

Thermal energy is stored in thermally insulated tanks, filled with pressurized steam at pressures between 50-70 bar and temperatures in the range of $280^{\circ} \mathrm{C}$. A closed loop is utilized either from the receiver to the thermal tank and consequently to the steam turbines, or directly from the receiver to the steam turbines. During storage under high pressure the steam is condensed. Steam is vaporized before use in the turbine by pressure release from the thermal tank. The storage capacity of the thermal tank is rather limited, due to high cost. This limitation permits use only for short-term storage applications, e.g., during rapid power demand in case of inadequate power production from the solar collectors.

Oils: Synthetic oils have been traditionally used as heat transfer fluid in CSP plants. Organic and non-edible vegetable oils with appropriate thermophysical properties have also been considered as low-cost alternatives [89]. Their liquid phase between $12{ }^{\circ} \mathrm{C}$ and $400{ }^{\circ} \mathrm{C}$ is advantageous compared to water. Another feature of synthetic oils is their low vapor pressure at high temperatures leading to reduced balance-of-system cost, due to low pipeline requirements. Synthetic oils, however, exhibit considerably low thermal conductivities, in the range of $0.1 \mathrm{~W} / \mathrm{m} \cdot \mathrm{K}$ and roughly $50 \%$ reduced specific heat capacity, compared to water [9].

Earth materials: Earth materials including rocks, gravel and sand offer an alternative option for thermal energy storage, due to a number of favorable features, like nonflammability, non-toxicity, low cost and local availability, relatively high specific heat capacity and thermal conductivity. A wide range of tested earth materials with high thermal conductivity and thermal capacity for thermal storage are presented in Figure 2 [90]. Apart from the above mentioned properties, other desirable features can be also high surface strength to withstand wear from abrasion due to repeating heat compression and expansion, low porosity, to prevent oil infiltration and high mechanical strength.

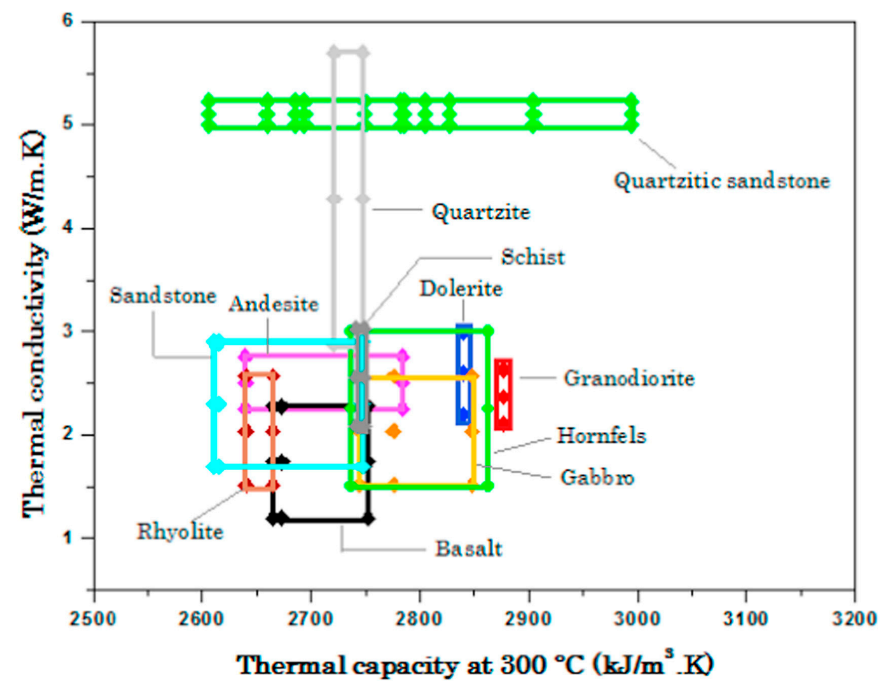

Figure 2. Thermal conductivity and thermal capacity of studied earth materials for CSP plants. Reprinted with permission [90]; 2017, Elsevier.

The chemical composition is a crucial parameter of earth materials as thermal storage media. For example, hydroxyl bonds in muscovite and biotite minerals in granite break 
under temperatures higher than $350{ }^{\circ} \mathrm{C}$, leading to a $3 \%$ mass loss [91]. Marble composed of $\mathrm{CaCO}_{3}$ exhibits similar mass loss at this temperature, due to exhaust of $\mathrm{CO}_{2}$. Unlike marble and granite, quartzite, basalt and hornfels are more thermally stable under heating up to $400{ }^{\circ} \mathrm{C}$, being more suitable for thermal storage processes.

Quartzite exhibits the highest thermal conductivity $(7.7 \mathrm{~W} / \mathrm{mK})$ and thermal storage capacity $\left(3822 \mathrm{~kJ} / \mathrm{m}^{3} \mathrm{~K}\right)$ from the other available earth materials for thermal storage [91]. This fact, along with stability under high temperature up to $400{ }^{\circ} \mathrm{C}$ makes quartzite the most appropriate for thermal energy storage. Suitable high temperature earth minerals are the quartzitic sandstone with a high silica content, basalte and hornfels [90,91].

Inside a thermal tank, earth materials are laid in layers to form a packed bed structure of variable grain distribution. Rocks of relatively large sizes such as stones, pebbles and gravel are used for packed bed fillers. Materials with smaller granule size, like sand, are used in fluidized beds. This configuration offers the option to utilize HTF pipelines through the fluidized bed. In this way, thermal energy can be directly transferred through conduction from the HTF to the thermal storage material, thereby eliminating the need for heat exchangers and associated costs. In addition, more surface area of thermal transfer can contribute to a higher storage efficiency. This configuration can further lead to an $80 \%$ reduction [92] of the required quantity of HTF.

Concrete: Concrete mixtures are under development with several small size thermal storage projects underway reporting promising results $[93,94]$. Concrete as a TES material exhibits some attractive features, such as low cost, good mechanical properties, non-toxicity and non-flammability.

An intercomparison of materials [95] commonly found in engineering databases compared the mechanical stability of concrete, ceramics and steel. Concrete and supersulphate cement have equally low cost with $\mathrm{NaCl}$. The high toughness but high cost of steel may be prohibitive for low cost sensible storage, however a middle ground can be reactive powder concrete [95].

Its relatively low thermal conductivity and specific heat, close to $0.5 \mathrm{~W} / \mathrm{mK}$ and $0.7 \mathrm{~kJ} / \mathrm{kgK}$ respectively, can be increased up to $0.719 \mathrm{~W} / \mathrm{mK}$ and $1.05 \mathrm{~kJ} / \mathrm{kgK}$ with additives such as silane coated silica fume [88]. Thermal storage in cement can operate at temperatures up to $400{ }^{\circ} \mathrm{C}$, while additives such as blast furnace slag a maximum temperature of $550^{\circ} \mathrm{C}$ can be reached [93].

Currently the specific set-up cost per unit of thermal storage capacity is $30 \mathrm{\$} / \mathrm{kWh}_{\mathrm{th}}$ with target reductions to $15 \$ / \mathrm{kWh}_{\text {th }}$ [96]. The first commercial generation of thermal storage systems with concrete slabs is available with nominal thermal storage capacities at $300-400 \mathrm{kWh}_{\text {th }}[97,98]$. Recently, storage systems up to $500 \mathrm{kWh}_{\text {th }}$ were reported based on modular designs of the same technology [99].

\subsection{Latent Energy Storage}

Latent heat storage can be utilized in the thermal energy absorbed by phase change materials (PCM) during their transition between solid and liquid phases. The available thermal energy in a PCM is proportional to its mass and its specific latent heat.

The most usually executed phase-change is solid to liquid. Expansion during phasechange in the range of $10 \%$ of the volume is acceptable for enclosures [100]. Solid to solid phase change exhibits reduced leakage risk and waives the need for enclosures, albeit the specific latent heat is less than solid to liquid. The liquid to gas phase change has the highest specific latent heat, however, the considerable expansion, requiring respectively large encapsulations that make it prohibitive for low-cost storage.

A wide range of organic and inorganic PCM has been reported. Organic PCM include paraffin, fatty acids, esters and alcohols with melting temperatures lower than $100{ }^{\circ} \mathrm{C}$ making them not suitable for CSP plants. The interested reader is directed towards reference [88] for a complete review. Inorganic molten salts, salt eutectics, as well as metals and alloys with melting temperatures from $250{ }^{\circ} \mathrm{C}$ up to $1500^{\circ} \mathrm{C}$ are promising candidates for energy storage in CSP plants. 
As shown in Figure 3, the energy density of PCM may vary between $70-1100 \mathrm{kWh} / \mathrm{m}^{3}$ while latent heat thermal storage capacity can be 50-100 times more than sensible heat storage.

In these systems, the HTF from the solar receiver flows through a heat exchanger embodied inside the PCM mass, transferring thermal energy from the receiver's loop to the thermal storage material. The main advantage of this technology is the high volumetric storage density and the low cost of the PCM. One of the main obstacles towards commercial development of the technology is the low thermal conductivity of existing PCM.

Molten salts and salt eutectics: Salts with melting points higher than $100{ }^{\circ} \mathrm{C}$ are currently employed as PCM for thermal storage processes. Additionally, latent heat thermal energy storage by using salts as PCM with high melting point, can offer high volumetric thermal storage capacity.

Inorganic salts, such as hydrates, nitrates, carbonates, chlorides, sulfates fluorides and hydroxides have been reported for PCM in TES [101]. Binary and ternary mixtures of nitrate salts exhibit the lowest melting points at $200^{\circ} \mathrm{C}$ [102]. For this reason, they are currently the most commonly employed PCM in solar thermal power plants. Hydroxides exhibit melting points, from $250{ }^{\circ} \mathrm{C}$ to $600{ }^{\circ} \mathrm{C}$, while carbonates, chlorides, sulfates and fluorides have melting temperatures higher than $600{ }^{\circ} \mathrm{C}$ [103].

Pure salts and salt eutectics with melting points higher than $250{ }^{\circ} \mathrm{C}$ [103] are suitable as PCM for latent heat storage. Latent heat thermal storage involves the PCM heating up process while being in the solid phase, until its melting point.

Molten salts exhibit melting points usually above $200^{\circ} \mathrm{C}$, due to which they can freeze in the pipelines, in the absence of any heat source. To circumvent this challenge a melting point close to the ambient temperature and a high boiling point is preferred, so the entire operating range of the heat transfer fluid could be utilized for energy storage.

The thermo-physical properties of pure salts can be adapted according to a thermal process in binary or ternary salt eutectics. In this way, the melting point of a PCM can be reduced, thereby extending the operating temperature range and reducing the solidification risk in the pipelines of a plant. Practically, binary and ternary eutectic mixtures are integrated for reduced melting points, without affecting the boiling point.

Molten salts have high thermal energy storage efficiency, due to their high volumetric heat capacity, which, combined with their low procurement cost, lead to low-cost storage. They also exhibit high boiling points, very high thermal stability and near-zero vapor pressure. The achieved storage temperatures up to $565^{\circ} \mathrm{C}$ [4], low toxicity and flammability, make them suitable for high-pressure and high-temperature steam turbines.

Molten salts are characterized with high viscosity, compared to water and synthetic oils, which imply high flow losses in the pipelines and increased pumping or circulating costs. Their corrosive impact is also significant, further exacerbated at high temperatures.

A higher cycle efficiency can be achieved due to a higher boiling point than synthetic oil or water. When the life-cycle of a CSP plant is complete, the employed molten salts can be crystallized and removed in solid phase for other uses, utilizing the experience of chemical and metallurgical industries in thermal processes [104].

An overview of available PCM is displayed along its cost, energy density and melting temperature in Figure 3. The most widely molten salt used in CSP plants is a mixture of sodium nitrate $\left(\mathrm{NaNO}_{3}\right)$ and potassium nitrate $\left(\mathrm{KNO}_{3}\right)_{)}$, known as solar salt. While pure $\mathrm{NaNO}_{3}$ and $\mathrm{KNO}_{3}$ have melting points of $307^{\circ} \mathrm{C}$ and $334^{\circ} \mathrm{C}$ respectively, the melting point of the binary mixture drops to $220^{\circ} \mathrm{C}$. Besides the melting temperature, their low cost makes them favorable. It can be seen that silicon has comparable cost with the traditional salts, but crucially an order of magnitude higher energy density. In addition to temperature and energy density, the thermophysical properties of each PCM have to be further evaluated identifying performance and cost optimization of a CSP plant [105]. 


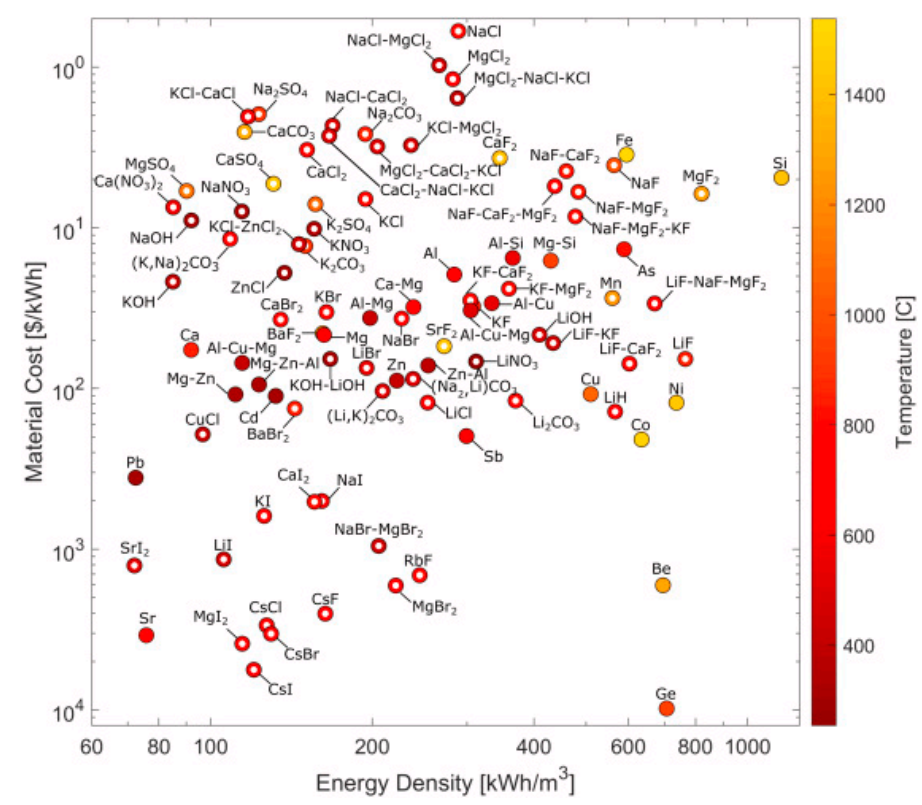

Figure 3. Energy density, cost and temperature of demonstrated phase-change materials for latent heat storage in CSP plants. Reprinted with permission [105]; 2020, Elsevier.

Advances in thermophysical properties: The plethora of available PCM [101,106] and molten salts $[102,107]$ have been tabulated in several reports along with their thermophysical properties of density, viscosity, thermal conductivity and heat capacity. During this heating process, thermal energy is transferred through the PCM mass by conduction. The thermal conductivity of PCM is remarkably low and their specific heat capacity is approximately $60 \%$ lower than water. Given the low thermal conductivity of inorganic salts, commonly between $0.5 \mathrm{~W} / \mathrm{m} \cdot \mathrm{K}$ and $1 \mathrm{~W} / \mathrm{m} \cdot \mathrm{K}$ [96], preliminary heating is performed with low efficiency and prolongs the duration of a thermal storage cycle. For this reason, the increase of the PCM thermal conductivity in the solid phase is crucial [103].

Extended surface: Research has been devoted to increase the thermal conductivity by extending the surface area of the storage enclosure. Aluminum is the most promising cost-wise with comparable conductivity to copper, while graphite foil and sheet are novel promising options [108]. The geometry of the fins is also crucial as shown in Figure 4. Tree-shaped fins exhibited $24 \%$ increased discharge efficiency when two bifurcations were added in the fin geometry [109]. Further extending the branch shape in agreement with thermodynamically efficient evolutionary designs [110] can increase the effective thermal conductivity in the range of 0.12 to $169 \mathrm{~W} / \mathrm{m} \cdot \mathrm{K}$ [111].

Encapsulation: Improved salt thermophysical properties have also been reported by addition of a few percent of silica [112] or cupric oxide [113] nanoparticles. $\mathrm{SiO}_{2}$ and $\mathrm{TiO}_{2}$ also exhibited improved performance as PCM encapsulation [114] comparing favorably to more expensive steel encapsulation [115]. For a detailed review on encapsulation technologies the reader is directed towards reference [116].

Metals and alloys: Metals and alloys have the highest thermal conductivity and the highest volumetric thermal storage capacity among alternative PCM. Considerable experience in reactors proposed lead-bismuth, sodium and sodium-potassium as alternatives. All three alternatives have appropriately low melting from $-12.6^{\circ} \mathrm{C}$ for sodium-potassium and high boiling point up to $1533^{\circ} \mathrm{C}$ for lead-bismuth [117]. A high temperature range while in liquid phase is promising for potential latent heat storage. High thermal conductivity up to $64.9 \mathrm{~W} / \mathrm{m} \cdot \mathrm{K}$ of pure sodium can reduce the wall temperature of the solar receiver, further reducing heat losses to the environment. These features make liquid metals promising HTF for improved receiver efficiency. High temperature leads to higher efficiency of the thermodynamic cycle by up to 50\% [9]. Despite these features, the high 
toxicity of lead-bismuth and high flammability of sodium and potassium are not favorable for wide application in CSP.
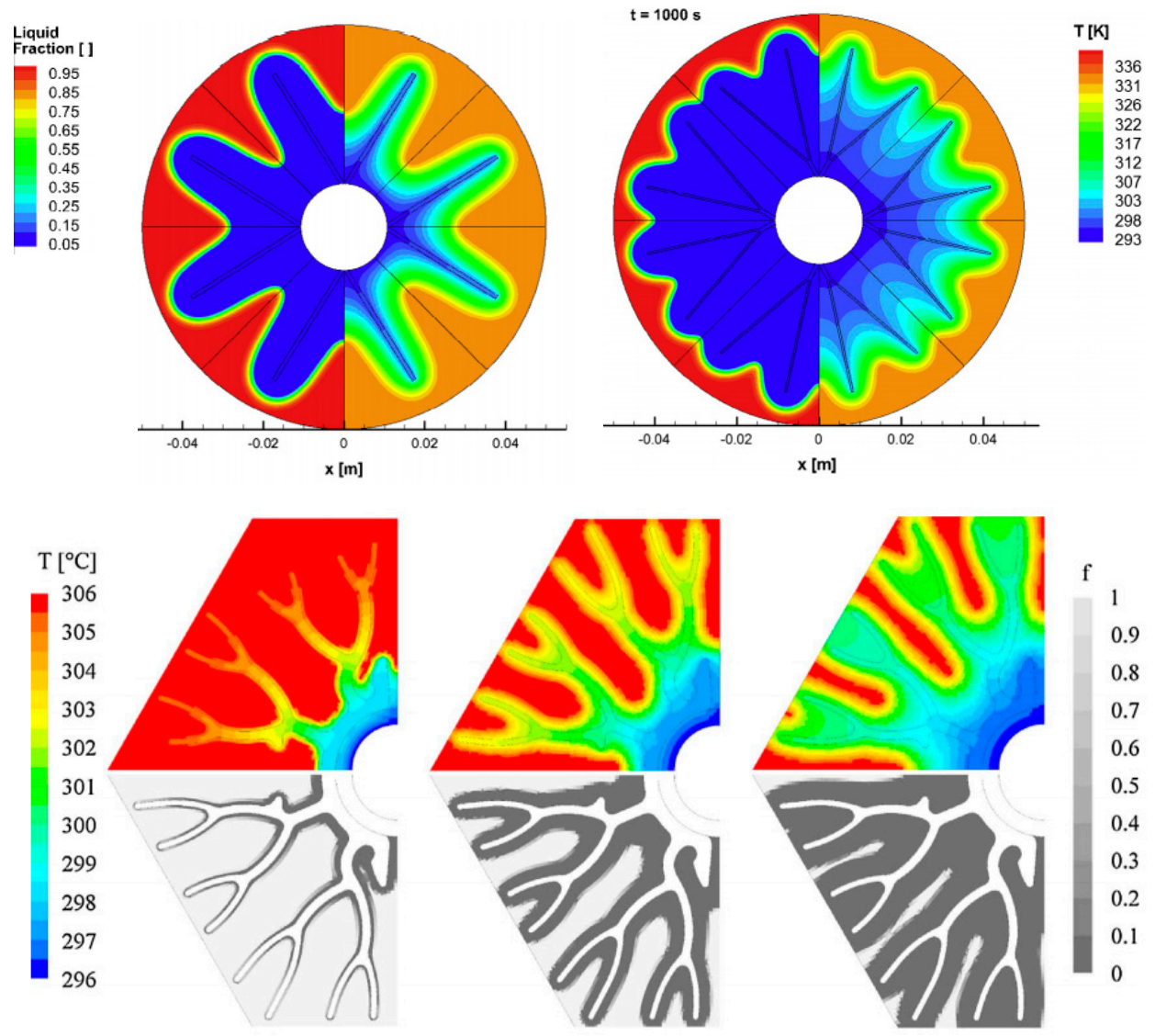

Figure 4. Extended surface fin designs of single (left) and double (right) bifurcations (above) and extended finned tube heating gradient at 100, 500 and $900 \mathrm{~s}$ (below). The temperature gradients and the liquid fraction of the phase-change material can be seen in the scales. Adapted with permission [109,111]. 2015, 2017 Elsevier.

Among a comprehensive list of available PCM, silicon and aluminum-silicon have reported the lowest $\mathrm{LCOE}$ for melting points $>1000{ }^{\circ} \mathrm{C}$ and $>400{ }^{\circ} \mathrm{C}$, respectively [105]. Industrial experience is advanced in both materials, however, their toxicity and stability is an area of further investigation if used for wide application in CSP. After repeated thermal cycles, however, their micro-structure may be altered due to precipitation, oxidation or segregation [88], which may alter their melting point and latent heat. Oxidation can be prevented by the use of inert gases in metals that do not absorb them during melting and solidification cycles [118]. On the other hand, among the major drawbacks of liquid metals as HTF and storage, their high procurement cost which necessitates optimization of the occupied volume and their sensitivity over corrosion.

\subsection{Thermochemical Heat Storage}

In thermochemical heat energy storage, solar radiation is employed to initiate an endothermic and reversible chemical reaction. The absorbed solar radiation is stored in the chemical potential of the reactants. During discharging, the stored thermal energy is recovered by the reverse exothermic reaction, often in the presence of a catalyst.

The volumetric energy density of thermochemical energy storage studies in solid and liquid reactants can be seen in Figure 5 [119]. It can be seen that thermochemical heat storage exhibits energy density, up to 10 times greater than latent heat storage. In addition, 
thermal energy storage may have considerably long duration at ambient temperature, making thermochemical heat storage an economically competitive option.

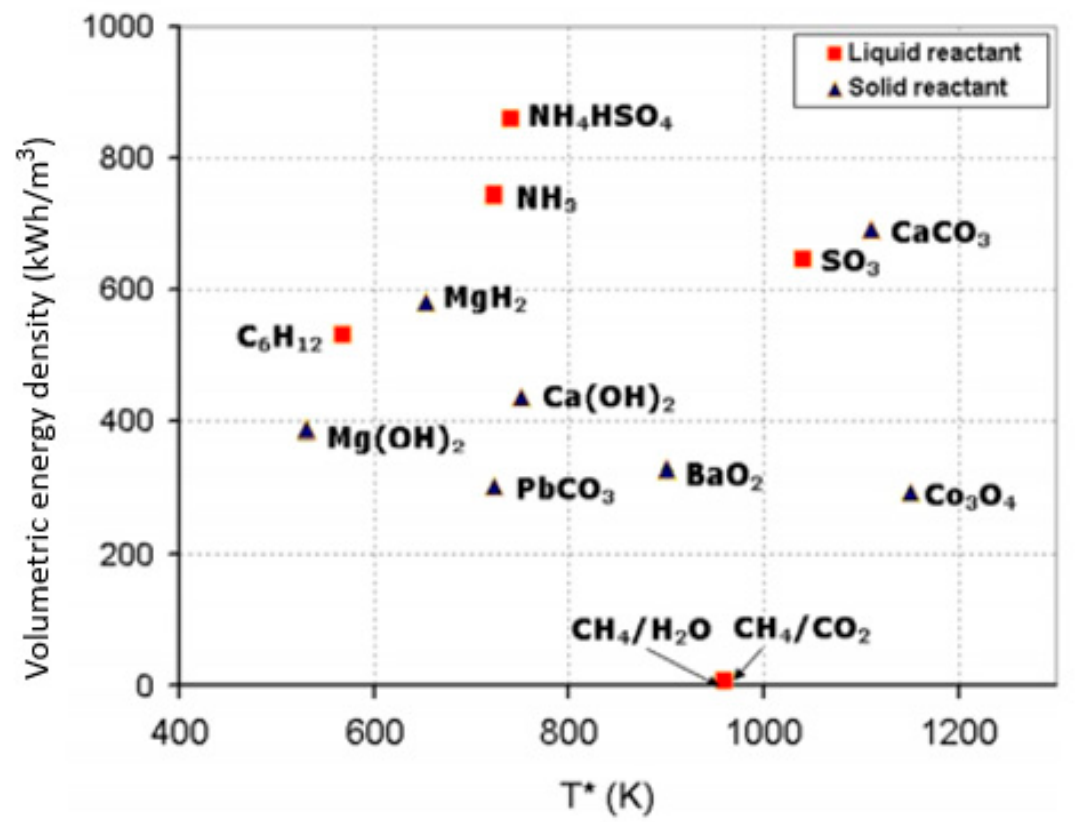

Figure 5. Volumetric energy density of demonstrated thermochemical storage with liquid and solid reactants. Reprint with permission [119]; 2014, Elsevier.

Thermochemical heat storage is performed at temperatures between $300-1000{ }^{\circ} \mathrm{C}$ with metal oxides and hydrides, carbonates, hydroxides, redox, ammonia and organic systems [119]. While several processes have been reported at $100 \mathrm{~kW}$ scales, the majority is reported at scales below $10 \mathrm{~kW}$ [120]. In conjunction with high operating temperatures, thermochemical storage would be demonstrable with parabolic dish collectors and suitable for SPT for scales beyond $100 \mathrm{~kW}$. Some thermochemical reactions are characterized with incomplete reversibility [121]. Incomplete rehydration of $\mathrm{MgO}$ was reported at $600{ }^{\circ} \mathrm{C}$ with $87.5 \%$ conversion to $\mathrm{Mg}(\mathrm{OH})_{2}$. The conversion is complete at a lower temperature of $375^{\circ} \mathrm{C}$ [122]. $\mathrm{PbO} / \mathrm{PbCO}_{3}$ and $\mathrm{BaO} / \mathrm{BaO}_{2}$ systems also exhibit incomplete conversion [119]. Reactions of hydrocarbon systems such as $\mathrm{CH}_{4} / \mathrm{CO}_{2}, \mathrm{CH}_{4} / \mathrm{H}_{2} \mathrm{O}$ and $\mathrm{C}_{6} \mathrm{H}_{12} / \mathrm{C}_{6} \mathrm{H}_{6}$ have also been tested however their reversibility is too low for further application [119]. This irreversibility constitutes a major drawback, since it contributes to the gradual reduction of the storage capacity, with repeated incomplete charging — discharging cycles. The $\mathrm{NH}_{3} / \mathrm{N}_{2} / \mathrm{H}_{2}$ system benefits also from multiple decades of experimental experience despite its incomplete conversion. Recently, transition metal ammoniates systematically tested exhibited improvements in cycle stability. In particular sulphates exhibited better reversibility over 10 cycles compared to chlorides [123] with the highest performance exhibited by the reaction couple $\mathrm{CuSO}_{4} /\left[\mathrm{Cu}\left(\mathrm{NH}_{3}\right)_{4}\right] \mathrm{SO}_{4}$. Solar decarbonization has also been considered as a promising route with production of hydrogen and 55\% solar-to-fuel maximum efficiency [124]. Particle reactors are considered for a high efficiency of this process, with appropriate designs presented in this review.

The reaction system should fulfill certain criteria for application in solar thermochemical storage. A minimum temperature between $300-400{ }^{\circ} \mathrm{C}$ is required for compatibility with PTC and SPT systems. Accordingly, the low temperatures of $\mathrm{Cr}-$, Li-, Mg- and Sb-based oxides, as well as $\mathrm{V}_{2} \mathrm{O}_{5}$ and $\mathrm{BaO}_{2}$ [125], exclude them from application in CSP. The high toxicity of $\mathrm{Pb}$-, Be-, $\mathrm{U}$ - and sulphur-based oxides, $\mathrm{Pb}$ - and $\mathrm{Cd}$-based carbonates make them unsuitable for safe application. $\mathrm{Co}_{3} \mathrm{O}_{4}$ exhibits fast reaction kinetics and complete reversibility, however, its carcinogenicity should be dealt with for wider application. The high cost of Pt- and Rh-based oxides are not competitive alternatives. Based on these criteria, candidates such as $\mathrm{Ca}-$, Sr- and Ba- carbonates and hydroxides, as well as $\mathrm{Co}-, \mathrm{Fe}-, \mathrm{Cu}^{-}$ 
and Mn- oxides fulfill the criteria for CSP systems and have been successfully tested [125], exhibiting promise for transition to large scale testing. The good reversibility $\mathrm{Cu}$ - and Co-based oxides [126] adds further points to their potential application. Co-based $\mathrm{ABO}_{3}$ perovskites in the $\mathrm{B}$ site, exhibited higher $\mathrm{O}_{2}$ exchange capacity and high reaction enthalpy compared to Fe- and Mn-based with Ba in A site [127], offering another novel system for thermochemical storage.

Another major technical issue is the storage of gas products of the reaction such as $\mathrm{H}_{2}$, $\mathrm{SO}_{3}$ and $\mathrm{NH}_{3}$, due to their increased volume. A potential solution could be compression and storage of these products in large tanks, however, inducing higher installation and operation costs. Alternative solutions can be the storage of $\mathrm{H}_{2}$ in metals hydrides at low temperatures or by adsorption, with respective additional costs. Adsorption-based energy storage may benefit from recent advances in metal-organic frameworks (MOFs) [128]. The advancement, however, has to be comply with reduced cost compared to alternatives due to the currently limited mass production of MOFs.

The hydration/dehydration of $\mathrm{CaO}$ constitutes another promising reaction with high energy density, good reversibility, low operating pressure price and toxicity of the products due to extensive experimental feedback [121]. The low thermal conductivity, agglomeration and sintering, however still require remedy. Low thermal conductivity constitutes a common drawback of materials used for thermochemical storage, leading to slow heat transfer rate. Additionally, low permeability is another common drawback, which reduces the mass transfer and decelerates the rate of chemical reaction. Research efforts are focused on enhancing the mass transfer during direct reaction and the heat transfer during the reverse reaction [121].

\section{Integration of Technologies}

Alternative solar thermal power plant integration imposes adaptation of thermal energy storage systems to each solar technology. Important parameters towards this integration are the power demand, the temperature and pressure of the working fluid in the receiver, the size of the solar thermal power plant and its operation algorithm.

The thermal energy storage alternative integration concepts can be classified into active and passive systems, depending on the state of the employed thermal storage medium. In active storage systems, the storage medium flows to absorb during the charging phase or disposes thermal energy during discharging phase by forced convection. In passive storage systems, however, the storage medium remains still while heated or cooled by the circulation of the heat transfer fluid.

Active systems can be either direct or indirect systems. In direct thermal energy storage, the thermal energy transfer medium is directly stored in thermal storage tanks. For the application of such a system, the thermal energy transfer medium should exhibit low cost and high thermal capacity. These two prerequisites control the thermal storage tank size for cost reductions.

Active direct storage: In active direct systems, there is only one working fluid, being both the HTF and the storage medium. The common working fluid circulates between the solar collectors and the thermal storage tanks. During storage operation mode, the working fluid absorbs the concentrated solar radiation on the receiver and directly stores it in the hot storage tank, connected at the output of the solar field. During thermal discharge operation phase, the hot stored medium is pumped from the hot tank and, after releasing its contained thermal energy in a heat exchanger or a boiler for steam production, it is stored in the cold tank, connected at the inlet of the solar field. From this tank, the working medium is transferred to the solar collectors to act as HTF of concentrated solar radiation. The necessity of heat exchangers for the thermal energy transfer between HTF and storage medium is eliminated. The employed working fluid must exhibit appropriate HTF and storage medium properties. Steam and molten salts with wide operating temperature range for latent heat storage are the most favorable materials for such systems. The main advantages of the direct active systems are the elimination of the heat exchanger and the 
separate storage of cold and hot storage. The low thermal energy density of steam, the high cost of molten salts and the possible freezing of molten salts inside the hydraulic network due to their high melting point, are the main drawbacks of this integration scheme.

Active indirect storage: In indirect thermal storage systems, concentrated solar radiation is collected to the working medium in the receiver and further transferred via heat exchangers to the storage, as shown in Figure 6, left. Indirect storage is introduced when the HTF is expensive as in the case of synthetic oil or storage is challenging, as in the case of steam. The main advantage of indirect storage is the low cost of thermal storage media, while the two main disadvantages are the heat transfer losses through the heat exchanger, as well as its high set-up cost. In active indirect systems, there are two different fluids employed as HTF and storage medium. Such a system consists of two thermal storage tanks, for high and low temperatures. During the thermal storage phase, the working fluid is pumped from the cold tank and led through a heat exchanger where it is heated by the HTF, which flows from the solar receivers. The hot thermal storage medium via a heat exchanger, is stored in the hot tank. During the discharge operation mode, the flow of the thermal storage medium is reversed, that is pumped from the hot tank and through a heat exchanger releases thermal energy to the HTF from the steam generator. In this way, the hot thermal tank substitutes the thermal power production from the solar collectors, when it is not available or not enough to support the predefined operation of the power plant. Indirect active systems with two tanks exhibit the advantage of separate storage of cold and hot materials, while having the cost and freezing disadvantages of direct systems.

Thermocline storage: The hot and cold media can be separated by stratification of temperatures. The cold material is concentrated lower than the hot material due to gravity in one thermocline tank. The zone between the hot and cold media, enhances the stratification inside the unique thermal tank by addition of filler materials, such as quartzite rocks, sand and concrete parts in the storage medium. In this way, the required quantity of the storage medium is reduced. With the construction of one thermal tank instead of two, a set-up cost percentage drop of the thermal storage plant up to $35 \%$ can be achieved [96]. A key factor is the configuration of potential fillers, especially in case of solid filling materials. In the case of concrete fillers, a packed-bed structure exhibits better temperature stratification, compared to channel-embedded structure, parallel-plate structure and rod-buddle structures [129]. The main advantage of indirect systems with one tank is reduced set-up cost, however, maintenance of temperature stratification in the tank may be challenging.

Passive storage: In passive storage systems HTF circulates through the mass of the thermal storage media. In case of sensible heat storage, the energy transfer from the HTF to the thermal tank is performed with tubular heat exchangers in the mass of the thermal material. High material thermal conductivity and considerable thermal energy exchange surface are crucial for higher thermal energy transfer rates. While passive storage is made of low-cost material combined with compact storage volumes and hence high heat transfer rates, the cold and hot materials are not separated affecting the discharge temperatures.

\subsection{Power Cycles, Combined and Hybrid}

The most common power cycle is the steam Rankine where water is heated at high and constant pressure to saturation. The saturated vapor expands through a turbine generator. Consequently, the condensed saturated liquid is pumped for further reheat and reuse in the cycle. The high temperature of steam Rankine cycles can be reduced by replacing water with organic compounds in small scale organic Rankine cycles with benefits in cost reduction [131]. Temperatures higher than the Rankine cycle are achieved in a Brayton cycle utilizing gas turbines. Recovery of hot steam at the output of turbines can increase the cycle efficiency [110] and combination of double and triple cycles [132] can be utilized in this end. 

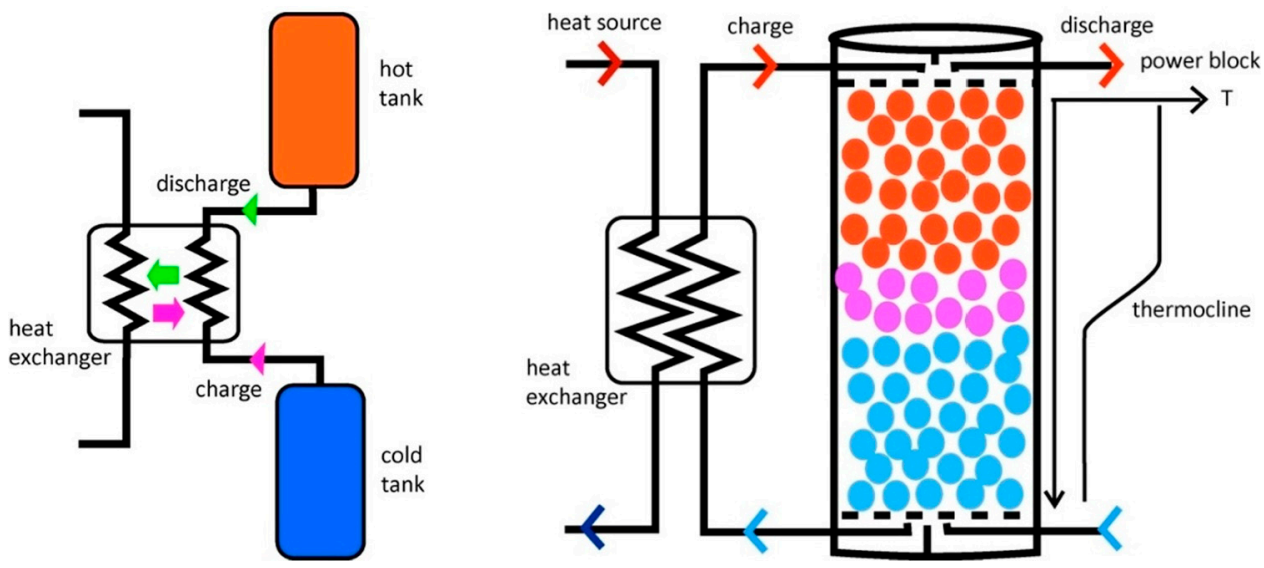

Figure 6. Two-tank indirect (left) and one-tank thermocline storage system (right). Reprint with permission [130]; 2017, Elsevier.

The operation of the whole system is usually facilitated with the introduction of a conventional heat production unit, aiming at the improvement of the cycle efficiency by increasing the exergy of the steam. In this way demand is supplemented after sunset and low solar radiation. In addition, the temperature of HTF or storage media is maintained above freezing temperatures.

Several renewable energy hybrid configurations have been reported. Co-location of resource favors CSP-biomass over alternatives, while the low temperatures of the CSPgeothermal hybrids are associated with a higher cost of investment [133]. The limited reports on CSP-wind hybrids indicate temporally, but not geographically complementary resources. Moreover, co-location is not required due to diversity between thermal and power electrical output, suggesting integration potential at the grid level [134]. Annual yield estimates report improvement from 3.4\% to $9.6 \%$ in CSP-biomass hybrids [135]. The net solar-to-electric efficiency of a $50 \mathrm{MW}$ hybrid plant can be improved to $18 \%$ [136] with over $20 \%$ investment reductions [137]. Storage integration in the hybrid cycle can increase the net efficiency by another $2 \%$ as estimated in small scale plants [138].

\subsection{Comparison and Complementary Technologies}

Table 1 summarizes the presented CSP technologies and compares their main characteristics. PTC and SPT have the highest efficiency and lowest LCOE among CSP technologies. More than $90 \%$ of a total $4 \mathrm{GW}$ solar thermal power plants installed globally are based on PTC and SPT [4].

Table 1. Performance metrics of CSP technologies [2,88].

\begin{tabular}{ccccc}
\hline & Temperature $\left({ }^{\circ} \mathbf{C}\right)$ & Solar Concentration & Efficiency (\%) & LCOE (\$/kWh) \\
\hline PTC & $20-400$ & $15-45$ & 25 & $0.16-0.40$ \\
LFR & $5-300$ & $10-40$ & 18 & $0.14-0.45$ \\
SPT & $300-1000$ & $150-1500$ & 22 & $0.13-0.30$ \\
PDC & $120-1500$ & $100-1000$ & 32 & n.a. \\
\hline
\end{tabular}

The major advantage of the SPT over PTC is higher operating temperature. Thermal energy at higher temperatures can be converted more efficiently to electricity. Another advantage of the SPT plants is the easier application of air-cooling in place of a watercooling system. Solar thermal power plants are installed in geographical areas with high solar radiation and low water resources, making air-cooling a suitable option.

SPT plants can be installed in inclined land surfaces, such as mountain slopes, sufficing the orientation of the heliostats towards the central receiver. Heliostats are cheaper than parabolic collectors, however, each heliostat requires dedicated two-axes tracking, while 
a single-axis tracking per parabolic trough collector assembly is sufficient. Moreover, a significant portion of the reflected solar radiation from the heliostats is scattered due to atmospheric attenuation, reducing the efficiency and performance of the power plant. Currently, the most important drawback of the SPT plants is the limited shared experience and technical data from installed plants. The simplicity of the SPT construction and the low cost of heliostats is promising for rapid increase of installed projects.

Lower cost is expected from developments in LFR, which utilize lighter structures and fixed receivers than the PTC. Moreover, the traditional north-south orientation of the PTC may not be optimum for LFR depending on the location [31]. The latter is also the case for combined PTC and SPT plants that exhibit complementary energy generation [139] and can lead to more than $10 \%$ higher solar exergy [140].

The development of the reviewed technologies cannot omit their cost-effective and environmentally-friendly [141] integration. As shown in Figure 7, a high demand at low availability of solar power may not coincide with high energy price, which makes energy storage a crucial component for system integration.

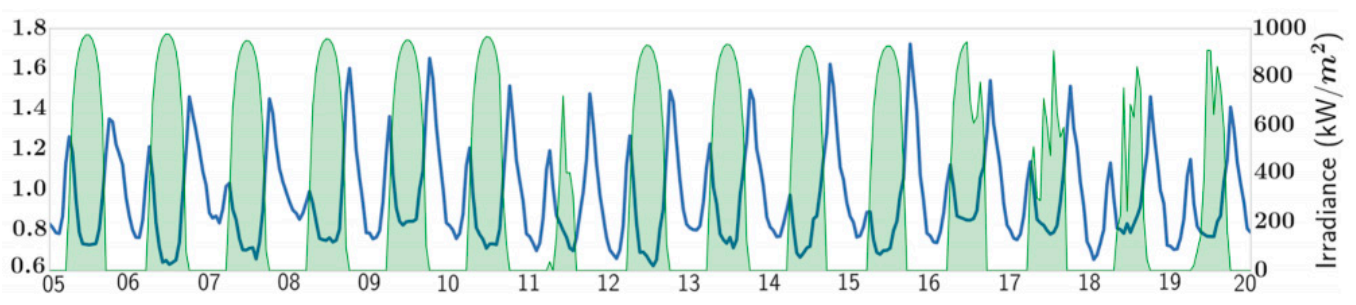

Figure 7. Typical solar irradiance energy price time-series of a solar thermal power plant. Reprint with permission [142]; 2018, Elsevier.

As a consequence, there are optimal revenue scenarios by generating energy when most needed. At a high price scenario, this can lead to more than $7 \%$ incoming improvements from a 50 MWe PTC plant, although at high price periods the need for auxiliary power source was needed [143]. The revenue improvements of the optimization for an SPT plant can be more than $8.5 \%$ for a 150 MWe SPT plant with molten salt storage [142]. The high investment costs of a unique PTC plant did not prove sustainable in Spanish markets despite subsidy support [144], indicating the need for technological innovation in concentrating solar power technologies.

With the cost of photovoltaic module and balance of system below 1 \$ W [145] and $2 € / \mathrm{Wp}$ [146], respectively, increasing penetration of photovoltaics is expected. This brings a significant challenge in electrical grids unprepared for a high content of intermittent renewable energy. Markets with increased penetration have already experienced this challenge and face significant curtailments of the produced energy $[147,148]$. For this reason, peak shifting via energy storage and efficient algorithms to the electrical grid is required. Currently, the price of solid state batteries and limited lifetime compared to photovoltaics, necessitates replacement with high cost for use in power plants. The reviewed advances in energy storage for concentrating solar power plants offer a low cost alternative for thermal storage of photovoltaic power via joule heating [149], despite its low thermodynamic efficiency. A recent analysis estimated LCOE as low as $0.04 € / \mathrm{kWh}$ for photovoltaics in countries with average insolation but high penetration. For thermal storage of CSP plants at LCOE of $0.15 € / \mathrm{kWh}$ a combined photovoltaic thermal storage plant results to LCOE of $0.09 € / \mathrm{kWh}[150]$.

\section{Conclusions}

In this review, the technological advances in concentrating solar power have been presented. Significant improvements in all components of the technology are crucial. Improvements in solar energy optics and configurations are crucial for higher optical efficiencies and higher solar concentration, as well as simpler alignment for cost reduction. Higher operating temperatures can further lead to higher cycle efficiencies. The higher 
temperature cannot go without the use of heat transfer fluids and energy storage materials with significant sensible and latent heat, to match a fluctuating demand and energy price. Last but not least, efficient algorithms orchestrating the multiple parts of the plant for a fluctuating demand are essential.

Author Contributions: Conceptualization, G.E.A. and D.A.K.; methodology, G.E.A. and D.A.K.; data curation, G.E.A.; writing - original draft preparation, G.E.A. and D.A.K.; writing-review and editing, G.E.A.; funding acquisition, G.E.A. and D.A.K. All authors have read and agreed to the published version of the manuscript.

Funding: This work was supported by an academic fellowship of the HMU Postdoctoral Research Program, 2021.

Institutional Review Board Statement: Not applicable.

Informed Consent Statement: Not applicable.

Acknowledgments: This work was supported by an academic fellowship of the HMU Postdoctoral Research Program, 2021.

Conflicts of Interest: The authors declare no conflict of interest.

\section{References}

1. Peinado Gonzalo, A.; Pliego Marugán, A.; García Márquez, F.P. A Review of the Application Performances of Concentrated Solar Power Systems. Appl. Energy 2019, 255, 113893. [CrossRef]

2. Weinstein, L.A.; Loomis, J.; Bhatia, B.; Bierman, D.M.; Wang, E.N.; Chen, G. Concentrating Solar Power. Chem. Rev. 2015, 115, 12797-12838. [CrossRef]

3. Mills, D.R.; Morrison, G.L. Compact Linear Fresnel Reflector Solar Thermal Powerplants. Sol. Energy 2000, 68, 263-283. [CrossRef]

4. González-Roubaud, E.; Pérez-Osorio, D.; Prieto, C. Review of Commercial Thermal Energy Storage in Concentrated Solar Power Plants: Steam vs. Molten Salts. Renew. Sustain. Energy Rev. 2017, 80, 133-148. [CrossRef]

5. Taylor, R.A.; Hewakuruppu, Y.; DeJarnette, D.; Otanicar, T.P. Comparison of Selective Transmitters for Solar Thermal Applications. Appl. Opt. 2016, 55, 3829-3839. [CrossRef] [PubMed]

6. Wang, Q.; Yang, H.; Hu, M.; Huang, X.; Li, J.; Pei, G. Preliminary Performance Study of a High-Temperature Parabolic Trough Solar Evacuated Receiver with an Inner Transparent Radiation Shield. Sol. Energy 2018, 173, 640-650. [CrossRef]

7. Wang, Q.; Hu, M.; Yang, H.; Cao, J.; Li, J.; Su, Y.; Pei, G. Performance Evaluation and Analyses of Novel Parabolic Trough Evacuated Collector Tubes with Spectrum-Selective Glass Envelope. Renew. Energy 2019, 138, 793-804. [CrossRef]

8. Atkinson, C.; Sansom, C.L.; Almond, H.J.; Shaw, C.P. Coatings for Concentrating Solar Systems-A Review. Renew. Sustain. Energy Rev. 2015, 45, 113-122. [CrossRef]

9. Benoit, H.; Spreafico, L.; Gauthier, D.; Flamant, G. Review of Heat Transfer Fluids in Tube-Receivers Used in Concentrating Solar Thermal Systems: Properties and Heat Transfer Coefficients. Renew. Sustain. Energy Rev. 2016, 55, 298-315. [CrossRef]

10. Zarza, E.; Valenzuela, L.; León, J.; Hennecke, K.; Eck, M.; Weyers, H.-D.; Eickhoff, M. Direct Steam Generation in Parabolic Troughs: Final Results and Conclusions of the DISS Project. Energy 2004, 29, 635-644. [CrossRef]

11. Khanna, S.; Kedare, S.B.; Singh, S. Analytical Expression for Circumferential and Axial Distribution of Absorbed Flux on a Bent Absorber Tube of Solar Parabolic Trough Concentrator. Sol. Energy 2013, 92, 26-40. [CrossRef]

12. Wirz, M.; Roesle, M.; Steinfeld, A. Three-Dimensional Optical and Thermal Numerical Model of Solar Tubular Receivers in Parabolic Trough Concentrators. J. Sol. Energy Eng. 2012, 134, 041012. [CrossRef]

13. Grena, R. Optical Simulation of a Parabolic Solar Trough Collector. Int. J. Sustain. Energy 2010, 29, 19-36. [CrossRef]

14. He, C.; Duan, X.; Zhao, Y.; Feng, J. An Analytical Flux Density Distribution Model with a Closed-Form Expression for a Flat Heliostat. Appl. Energy 2019, 251, 113310. [CrossRef]

15. Riffelmann, K.-J.; Neumann, A.; Ulmer, S. Performance Enhancement of Parabolic Trough Collectors by Solar Flux Measurement in the Focal Region. Sol. Energy 2006, 80, 1303-1313. [CrossRef]

16. Schiricke, B.; Pitz-Paal, R.; Lüpfert, E.; Pottler, K.; Pfänder, M.; Riffelmann, K.-J.; Neumann, A. Experimental Verification of Optical Modeling of Parabolic Trough Collectors by Flux Measurement. J. Sol. Energy Eng. 2009, 131, 011004. [CrossRef]

17. Cheng, Z.D.; He, Y.L.; Xiao, J.; Tao, Y.B.; Xu, R.J. Three-Dimensional Numerical Study of Heat Transfer Characteristics in the Receiver Tube of Parabolic Trough Solar Collector. Int. Commun. Heat Mass Transf. 2010, 37, 782-787. [CrossRef]

18. Cheng, Z.D.; He, Y.L.; Cui, F.Q.; Xu, R.J.; Tao, Y.B. Numerical Simulation of a Parabolic Trough Solar Collector with Nonuniform Solar Flux Conditions by Coupling FVM and MCRT Method. Sol. Energy 2012, 86, 1770-1784. [CrossRef]

19. Cheng, Z.D.; He, Y.L.; Cui, F.Q. A New Modelling Method and Unified Code with MCRT for Concentrating Solar Collectors and Its Applications. Appl. Energy 2013, 101, 686-698. [CrossRef]

20. Wang, Y.; Liu, Q.; Lei, J.; Jin, H. A Three-Dimensional Simulation of a Parabolic Trough Solar Collector System Using Molten Salt as Heat Transfer Fluid. Appl. Therm. Eng. 2014, 70, 462-476. [CrossRef] 
21. Xiao, X.; Zhang, P.; Shao, D.D.; Li, M. Experimental and Numerical Heat Transfer Analysis of a V-Cavity Absorber for Linear Parabolic Trough Solar Collector. Energy Convers. Manag. 2014, 86, 49-59. [CrossRef]

22. Tsai, C.-Y.; Lin, P.D. Optimized Variable-Focus-Parabolic-Trough Reflector for Solar Thermal Concentrator System. Sol. Energy 2012, 86, 1164-1172. [CrossRef]

23. Widyolar, B.; Jiang, L.; Ferry, J.; Winston, R.; Cygan, D.; Abbasi, H. Experimental Performance of a Two-Stage $(50 \times)$ Parabolic Trough Collector Tested to $650{ }^{\circ} \mathrm{C}$ Using a Suspended Particulate Heat Transfer Fluid. Appl. Energy 2019, 240, 436-445. [CrossRef]

24. Wirz, M.; Petit, J.; Haselbacher, A.; Steinfeld, A. Potential Improvements in the Optical and Thermal Efficiencies of Parabolic Trough Concentrators. Sol. Energy 2014, 107, 398-414. [CrossRef]

25. Gomes, E.T.A.; Fraidenraich, N.; Vilela, O.C.; Oliveira, C.A.A.; Gordon, J.M. Aplanats and Analytic Modeling of Their Optical Properties for Linear Solar Concentrators with Tubular Receivers. Sol. Energy 2019, 191, 697-706. [CrossRef]

26. Wang, Q.; Yang, H.; Zhong, S.; Huang, Y.; Hu, M.; Cao, J.; Pei, G.; Yang, H. Comprehensive Experimental Testing and Analysis on Parabolic Trough Solar Receiver Integrated with Radiation Shield. Appl. Energy 2020, 268, 115004. [CrossRef]

27. Wang, Q.; Yang, H.; Hu, M.; Cao, J.; Pei, G.; Yang, H. Optimization Strategies and Verifications of Negative Thermal-Flux Region Occurring in Parabolic Trough Solar Receiver. J. Clean. Prod. 2021, 278, 123407. [CrossRef]

28. Wang, Q.; Shen, B.; Huang, J.; Yang, H.; Pei, G.; Yang, H. A Spectral Self-Regulating Parabolic Trough Solar Receiver Integrated with Vanadium Dioxide-Based Thermochromic Coating. Appl. Energy 2021, 285, 116453. [CrossRef]

29. Wang, Q.; Pei, G.; Yang, H. Techno-Economic Assessment of Performance-Enhanced Parabolic Trough Receiver in Concentrated Solar Power Plants. Renew. Energy 2021, 167, 629-643. [CrossRef]

30. Abbas, R.; Montes, M.J.; Piera, M.; Martínez-Val, J.M. Solar Radiation Concentration Features in Linear Fresnel Reflector Arrays. Energy Convers. Manag. 2012, 54, 133-144. [CrossRef]

31. Abbas, R.; Montes, M.J.; Rovira, A.; Martínez-Val, J.M. Parabolic Trough Collector or Linear Fresnel Collector? A Comparison of Optical Features Including Thermal Quality Based on Commercial Solutions. Sol. Energy 2016, 124, 198-215. [CrossRef]

32. Qiu, Y.; He, Y.-L.; Cheng, Z.-D.; Wang, K. Study on Optical and Thermal Performance of a Linear Fresnel Solar Reflector Using Molten Salt as HTF with MCRT and FVM Methods. Appl. Energy 2015, 146, 162-173. [CrossRef]

33. Qiu, Y.; He, Y.-L.; Wu, M.; Zheng, Z.-J. A Comprehensive Model for Optical and Thermal Characterization of a Linear Fresnel Solar Reflector with a Trapezoidal Cavity Receiver. Renew. Energy 2016, 97, 129-144. [CrossRef]

34. Boito, P.; Grena, R. Optimization of the Geometry of Fresnel Linear Collectors. Sol. Energy 2016, 135, 479-486. [CrossRef]

35. Rabl, A. Active Solar Collectors and Their Applications; Oxford University Press: Oxford, UK, 1985; ISBN 978-0-19-536521-4.

36. Barlev, D.; Vidu, R.; Stroeve, P. Innovation in Concentrated Solar Power. Sol. Energy Mater. Sol. Cells 2011, 95, $2703-2725$. [CrossRef]

37. Poullikkas, A. Economic Analysis of Power Generation from Parabolic Trough Solar Thermal Plants for the Mediterranean Region-A Case Study for the Island of Cyprus. Renew. Sustain. Energy Rev. 2009, 13, 2474-2484. [CrossRef]

38. Pitman, C.L.; Vant-Hull, L.L. Atmospheric Transmittance Model for a Solar Beam Propagating between a Heliostat and a Receiver; Sandia National Labs.: Albuquerque, NM, USA; Houston University: Houston, TX, USA, 1984.

39. Sengupta, M.; Wagner, M. Estimating Atmospheric Attenuation in Central Receiver Systems; American Society of Mechanical Engineers Digital Collection: San Diego, CA, USA, 2013; pp. 399-403.

40. Hanrieder, N.; Sengupta, M.; Xie, Y.; Wilbert, S.; Pitz-Paal, R. Modeling Beam Attenuation in Solar Tower Plants Using Common DNI Measurements. Sol. Energy 2016, 129, 244-255. [CrossRef]

41. Christian, A. Gueymard Visibility, Aerosol Conditions, and Irradiance Attenuation Close to the Ground-Comments on "Solar Radiation Attenuation in Solar Tower Plants" by J. Ballestrin and A. Marzo, Solar Energy (2012). Sol. Energy 2012, 86, 1667-1668. [CrossRef]

42. Polo, J.; Estalayo, G. Impact of Atmospheric Aerosol Loads on Concentrating Solar Power Production in Arid-Desert Sites. Sol. Energy 2015, 115, 621-631. [CrossRef]

43. Ballestrín, J.; Marzo, A. Solar Radiation Attenuation in Solar Tower Plants. Sol. Energy 2012, 86, 388-392. [CrossRef]

44. Polo, J.; Ballestrín, J.; Alonso-Montesinos, J.; López-Rodriguez, G.; Barbero, J.; Carra, E.; Fernández-Reche, J.; Bosch, J.L.; Batlles, F.J. Analysis of Solar Tower Plant Performance Influenced by Atmospheric Attenuation at Different Temporal Resolutions Related to Aerosol Optical Depth. Sol. Energy 2017, 157, 803-810. [CrossRef]

45. Polo, J.; Ballestrín, J.; Carra, E. Sensitivity Study for Modelling Atmospheric Attenuation of Solar Radiation with Radiative Transfer Models and the Impact in Solar Tower Plant Production. Sol. Energy 2016, 134, 219-227. [CrossRef]

46. Carra, E.; Marzo, A.; Ballestrín, J.; Polo, J.; Barbero, J.; Alonso-Montesinos, J.; Monterreal, R.; Abreu, E.F.M.; Fernández-Reche, J Atmospheric Extinction Levels of Solar Radiation Using Aerosol Optical Thickness Satellite Data. Validation Methodology with Measurement System. Renew. Energy 2020, 149, 1120-1132. [CrossRef]

47. Hanrieder, N.; Wilbert, S.; Mancera-Guevara, D.; Buck, R.; Giuliano, S.; Pitz-Paal, R. Atmospheric Extinction in Solar Tower Plants-A Review. Sol. Energy 2017, 152, 193-207. [CrossRef]

48. Vant-Hull, L.L. The Role of "Allowable Flux Density" in the Design and Operation of Molten-Salt Solar Central Receivers. J. Sol. Energy Eng. 2002, 124, 165-169. [CrossRef]

49. Collado, F.J.; Guallar, J. A Two-Parameter Aiming Strategy to Reduce and Flatten the Flux Map in Solar Power Tower Plants. Sol. Energy 2019, 188, 185-189. [CrossRef] 
50. Yu, Q.; Wang, Z.; Xu, E. Analysis and Improvement of Solar Flux Distribution inside a Cavity Receiver Based on Multi-Focal Points of Heliostat Field. Appl. Energy 2014, 136, 417-430. [CrossRef]

51. Collado, F.J.; Guallar, J. A Review of Optimized Design Layouts for Solar Power Tower Plants with Campo Code. Renew. Sustain. Energy Rev. 2013, 20, 142-154. [CrossRef]

52. Collado, F.J.; Guallar, J. Quick Design of Regular Heliostat Fields for Commercial Solar Tower Power Plants. Energy 2019, 178, 115-125. [CrossRef]

53. Carrizosa, E.; Domínguez-Bravo, C.; Fernández-Cara, E.; Quero, M. A Heuristic Method for Simultaneous Tower and Pattern-Free Field Optimization on Solar Power Systems. Comput. Oper. Res. 2015, 57, 109-122. [CrossRef]

54. Li, L.; Coventry, J.; Bader, R.; Pye, J.; Lipiński, W. Optics of Solar Central Receiver Systems: A Review. Opt. Express 2016, 24, A985-A1007. [CrossRef] [PubMed]

55. Cruz, N.C.; Redondo, J.L.; Berenguel, M.; Álvarez, J.D.; Ortigosa, P.M. Review of Software for Optical Analyzing and Optimizing Heliostat Fields. Renew. Sustain. Energy Rev. 2017, 72, 1001-1018. [CrossRef]

56. Jafrancesco, D.; Cardoso, J.P.; Mutuberria, A.; Leonardi, E.; Les, I.; Sansoni, P.; Francini, F.; Fontani, D. Optical Simulation of a Central Receiver System: Comparison of Different Software Tools. Renew. Sustain. Energy Rev. 2018, 94, 792-803. [CrossRef]

57. Schramek, P.; Mills, D.R. Multi-Tower Solar Array. Sol. Energy 2003, 75, 249-260. [CrossRef]

58. Schramek, P.; Mills, D.R. Heliostats for Maximum Ground Coverage. Energy 2004, 29, 701-713. [CrossRef]

59. Belaid, A.; Filali, A.; Gama, A.; Bezza, B.; Arrif, T.; Bouakba, M. Design Optimization of a Solar Tower Power Plant Heliostat Field by Considering Different Heliostat Shapes. Int. J. Energy Res. 2020, 44, 11524-11541. [CrossRef]

60. Pfahl, A.; Coventry, J.; Röger, M.; Wolfertstetter, F.; Vásquez-Arango, J.F.; Gross, F.; Arjomandi, M.; Schwarzbözl, P.; Geiger, M.; Liedke, P. Progress in Heliostat Development. Sol. Energy 2017, 152, 3-37. [CrossRef]

61. Hertel, J.D.; Canals, V.; Pujol-Nadal, R. On-Site Optical Characterization of Large-Scale Solar Collectors through Ray-Tracing Optimization. Appl. Energy 2020, 262, 114546. [CrossRef]

62. Carretero, E.; Preciado, J.; Salinas, I.; Ayora, I.; Heras, C. Evaluation and Measurement of Heliostat Misalignment in Solar Power Plant Using Vector Model. Opt. Express 2019, 27, A257-A268. [CrossRef]

63. Sánchez-González, A.; Grange, B.; Caliot, C.; Caliot, C. Computation of Canting Errors in Heliostats by Flux Map Fitting: Experimental Assessment. Opt. Express 2020, 28, 39868-39889. [CrossRef] [PubMed]

64. Leonardi, E. Detailed Analysis of the Solar Power Collected in a Beam-down Central Receiver System. Sol. Energy 2012, 86, 734-745. [CrossRef]

65. Wei, X.; Lu, Z.; Yu, W.; Xu, W. Ray Tracing and Simulation for the Beam-down Solar Concentrator. Renew. Energy 2013, 50, 161-167. [CrossRef]

66. Li, L.; Wang, B.; Bader, R.; Zapata, J.; Lipiński, W. Reflective Optics for Redirecting Convergent Radiative Beams in Concentrating Solar Applications. Sol. Energy 2019, 191, 707-718. [CrossRef]

67. Li, L.; Wang, B.; Pye, J.; Bader, R.; Bader, R.; Wang, W.; Lipiński, W. Optical Analysis of a Multi-Aperture Solar Central Receiver System for High-Temperature Concentrating Solar Applications. Opt. Express 2020, 28, 37654-37668. [CrossRef] [PubMed]

68. Vant-Hull, L. Issues with Beam-down Concepts. Energy Procedia 2014, 49, 257-264. [CrossRef]

69. Li, H.; Huang, W.; Huang, F.; Hu, P.; Chen, Z. Optical Analysis and Optimization of Parabolic Dish Solar Concentrator with a Cavity Receiver. Sol. Energy 2013, 92, 288-297. [CrossRef]

70. Xia, X.-L.; Dai, G.-L.; Shuai, Y. Experimental and Numerical Investigation on Solar Concentrating Characteristics of a Sixteen-Dish Concentrator. Int. J. Hydrogen Energy 2012, 37, 18694-18703. [CrossRef]

71. He, Y.L.; Cheng, Z.D.; Cui, F.Q.; Li, Z.Y.; Li, D. Numerical Investigations on a Pressurized Volumetric Receiver: Solar Concentrating and Collecting Modelling. Renew. Energy 2012, 44, 368-379. [CrossRef]

72. Li, Z.; Tang, D.; Du, J.; Li, T. Study on the Radiation Flux and Temperature Distributions of the Concentrator-Receiver System in a Solar Dish/Stirling Power Facility. Appl. Therm. Eng. 2011, 31, 1780-1789. [CrossRef]

73. Cui, F.-Q.; He, Y.-L.; Cheng, Z.-D.; Li, Y.-S. Modeling of the Dish Receiver with the Effect of Inhomogeneous Radiation Flux Distribution. Heat Transf. Eng. 2014, 35, 780-790. [CrossRef]

74. Arnaoutakis, G.E.; Richards, B.S. Geometrical Concentration for Enhanced Up-Conversion: A Review of Recent Results in Energy and Biomedical Applications. Opt. Mater. 2018, 83, 47-54. [CrossRef]

75. Shuai, Y.; Xia, X.-L.; Tan, H.-P. Radiation Performance of Dish Solar Concentrator/Cavity Receiver Systems. Sol. Energy 2008, 82, 13-21. [CrossRef]

76. Yong, S.; Fu-Qiang, W.; Xin-Lin, X.; He-Ping, T.; Ying-Chun, L. Radiative Properties of a Solar Cavity Receiver/Reactor with Quartz Window. Int. J. Hydrogen Energy 2011, 36, 12148-12158. [CrossRef]

77. Wang, Q.; Yao, Y.; Hu, M.; Cao, J.; Qiu, Y.; Yang, H. An Air Curtain Surrounding the Solar Tower Receiver for Effective Reduction of Convective Heat Loss. Sustain. Cities Soc. 2021, 71, 103007. [CrossRef]

78. Zhang, Q.; Li, X.; Wang, Z.; Zhang, J.; El-Hefni, B.; Xu, L. Modeling and Simulation of a Molten Salt Cavity Receiver with Dymola. Energy 2015, 93, 1373-1384. [CrossRef]

79. Tu, N.; Wei, J.; Fang, J. Numerical Investigation on Uniformity of Heat Flux for Semi-Gray Surfaces inside a Solar Cavity Receiver. Sol. Energy 2015, 112, 128-143. [CrossRef]

80. Wang, K.; He, Y.-L.; Qiu, Y.; Zhang, Y. A Novel Integrated Simulation Approach Couples MCRT and Gebhart Methods to Simulate Solar Radiation Transfer in a Solar Power Tower System with a Cavity Receiver. Renew. Energy 2016, 89, 93-107. [CrossRef] 
81. Zhang, L.; Fang, J.; Wei, J.; Yang, G. Numerical Investigation on the Thermal Performance of Molten Salt Cavity Receivers with Different Structures. Appl. Energy 2017, 204, 966-978. [CrossRef]

82. Augsburger, G.; Favrat, D. Modelling of the Receiver Transient Flux Distribution Due to Cloud Passages on a Solar Tower Thermal Power Plant. Sol. Energy 2013, 87, 42-52. [CrossRef]

83. Buck, R.; Barth, C.; Eck, M.; Steinmann, W.-D. Dual-Receiver Concept for Solar Towers. Sol. Energy 2006, 80, 1249-1254. [CrossRef]

84. Luo, Y.; Du, X.; Wen, D. Novel Design of Central Dual-Receiver for Solar Power Tower. Appl. Therm. Eng. 2015, 91, 1071-1081. [CrossRef]

85. Ho, C.K. Advances in Central Receivers for Concentrating Solar Applications. Sol. Energy 2017, 152, 38-56. [CrossRef]

86. Ho, C.K. A Review of High-Temperature Particle Receivers for Concentrating Solar Power. Appl. Therm. Eng. 2016, 109, 958-969. [CrossRef]

87. He, Y.-L. Perspective of Concentrating Solar Power. Energy 2020, 198, 117373. [CrossRef]

88. Alva, G.; Lin, Y.; Fang, G. An Overview of Thermal Energy Storage Systems. Energy 2018, 144, 341-378. [CrossRef]

89. Kenda, E.S.; N’Tsoukpoe, K.E.; Ouédraogo, I.W.K.; Coulibaly, Y.; Py, X.; Ouédraogo, F.M.A.W. Jatropha Curcas Crude Oil as Heat Transfer Fluid or Thermal Energy Storage Material for Concentrating Solar Power Plants. Energy Sustain. Dev. 2017, 40, 59-67. [CrossRef]

90. Tiskatine, R.; Oaddi, R.; Ait El Cadi, R.; Bazgaou, A.; Bouirden, L.; Aharoune, A.; Ihlal, A. Suitability and Characteristics of Rocks for Sensible Heat Storage in CSP Plants. Sol. Energy Mater. Sol. Cells 2017, 169, 245-257. [CrossRef]

91. Grirate, H.; Agalit, H.; Zari, N.; Elmchaouri, A.; Molina, S.; Couturier, R. Experimental and Numerical Investigation of Potential Filler Materials for Thermal Oil Thermocline Storage. Sol. Energy 2016, 131, 260-274. [CrossRef]

92. Calvet, N.; Gomez, J.C.; Faik, A.; Roddatis, V.V.; Meffre, A.; Glatzmaier, G.C.; Doppiu, S.; Py, X. Compatibility of a Post-Industrial Ceramic with Nitrate Molten Salts for Use as Filler Material in a Thermocline Storage System. Appl. Energy 2013, 109, $387-393$. [CrossRef]

93. Alonso, M.C.; Vera-Agullo, J.; Guerreiro, L.; Flor-Laguna, V.; Sanchez, M.; Collares-Pereira, M. Calcium Aluminate Based Cement for Concrete to Be Used as Thermal Energy Storage in Solar Thermal Electricity Plants. Cem. Concr. Res. 2016, 82, 74-86. [CrossRef]

94. Girardi, F.; Giannuzzi, G.M.; Mazzei, D.; Salomoni, V.; Majorana, C.; Di Maggio, R. Recycled Additions for Improving the Thermal Conductivity of Concrete in Preparing Energy Storage Systems. Constr. Build. Mater. 2017, 135, 565-579. [CrossRef]

95. Fernandez, A.I.; Martínez, M.; Segarra, M.; Martorell, I.; Cabeza, L.F. Selection of Materials with Potential in Sensible Thermal Energy Storage. Sol. Energy Mater. Sol. Cells 2010, 94, 1723-1729. [CrossRef]

96. Gil, A.; Medrano, M.; Martorell, I.; Lázaro, A.; Dolado, P.; Zalba, B.; Cabeza, L.F. State of the Art on High Temperature Thermal Energy Storage for Power Generation. Part 1-Concepts, Materials and Modellization. Renew. Sustain. Energy Rev. 2010, 14, 31-55. [CrossRef]

97. Laing, D.; Lehmann, D.; Fiß, M.; Bahl, C. Test Results of Concrete Thermal Energy Storage for Parabolic Trough Power Plants. J. Sol. Energy Eng. 2009, 131. [CrossRef]

98. Sattler, J.C.; Caminos, R.A.C.; Ürlings, N.; Dutta, S.; Ruiz, V.; Kalogirou, S.; Ktistis, P.; Agathokleous, R.; Jung, C.; Alexopoulos, S.; et al. Operational Experience and Behaviour of a Parabolic Trough Collector System with Concrete Thermal Energy Storage for Process Steam Generation in Cyprus. AIP Conf. Proc. 2020, 2303, 140004. [CrossRef]

99. Hoivik, N.; Greiner, C.; Barragan, J.; Iniesta, A.C.; Skeie, G.; Bergan, P.; Blanco-Rodriguez, P.; Calvet, N. Long-Term Performance Results of Concrete-Based Modular Thermal Energy Storage System. J. Energy Storage 2019, 24, 100735. [CrossRef]

100. Cárdenas, B.; León, N. High Temperature Latent Heat Thermal Energy Storage: Phase Change Materials, Design Considerations and Performance Enhancement Techniques. Renew. Sustain. Energy Rev. 2013, 27, 724-737. [CrossRef]

101. Hoshi, A.; Mills, D.R.; Bittar, A.; Saitoh, T.S. Screening of High Melting Point Phase Change Materials (PCM) in Solar Thermal Concentrating Technology Based on CLFR. Sol. Energy 2005, 79, 332-339. [CrossRef]

102. Nunes, V.M.B.; Queirós, C.S.; Lourenço, M.J.V.; Santos, F.J.V.; Nieto de Castro, C.A. Molten Salts as Engineering Fluids-A Review: Part I. Molten Alkali Nitrates. Appl. Energy 2016, 183, 603-611. [CrossRef]

103. Myers, P.D.; Goswami, D.Y. Thermal Energy Storage Using Chloride Salts and Their Eutectics. Appl. Therm. Eng. 2016, 109, 889-900. [CrossRef]

104. Royo, P.; Acevedo, L.; Ferreira, V.J.; García-Armingol, T.; López-Sabirón, A.M.; Ferreira, G. High-Temperature PCM-Based Thermal Energy Storage for Industrial Furnaces Installed in Energy-Intensive Industries. Energy 2019, 173, 1030-1040. [CrossRef]

105. Rea, J.E.; Toberer, E.S.; Siegel, N.P. Guidelines for Phase Change Material Selection Based on a Holistic System Model. Sol. Energy Mater. Sol. Cells 2020, 208, 110422. [CrossRef]

106. Jiang, Y.; Liu, M.; Sun, Y. Review on the Development of High Temperature Phase Change Material Composites for Solar Thermal Energy Storage. Sol. Energy Mater. Sol. Cells 2019, 203, 110164. [CrossRef]

107. Serrano-López, R.; Fradera, J.; Cuesta-López, S. Molten Salts Database for Energy Applications. Chem. Eng. Process. Process Intensif. 2013, 73, 87-102. [CrossRef]

108. Reddy, K.S.; Mudgal, V.; Mallick, T.K. Review of Latent Heat Thermal Energy Storage for Improved Material Stability and Effective Load Management. J. Energy Storage 2018, 15, 205-227. [CrossRef]

109. Sciacovelli, A.; Gagliardi, F.; Verda, V. Maximization of Performance of a PCM Latent Heat Storage System with Innovative Fins. Appl. Energy 2015, 137, 707-715. [CrossRef]

110. Bejan, A.; Tsatsaronis, G. Purpose in Thermodynamics. Energies 2021, 14, 408. [CrossRef] 
111. Johnson, M.; Vogel, J.; Hempel, M.; Hachmann, B.; Dengel, A. Design of High Temperature Thermal Energy Storage for High Power Levels. Sustain. Cities Soc. 2017, 35, 758-763. [CrossRef]

112. Ercole, D.; Manca, O.; Vafai, K. An Investigation of Thermal Characteristics of Eutectic Molten Salt-Based Nanofluids. Int. Commun. Heat Mass Transf. 2017, 87, 98-104. [CrossRef]

113. Myers, P.D.; Alam, T.E.; Kamal, R.; Goswami, D.Y.; Stefanakos, E. Nitrate Salts Doped with CuO Nanoparticles for Thermal Energy Storage with Improved Heat Transfer. Appl. Energy 2016, 165, 225-233. [CrossRef]

114. Arconada, N.; Arribas, L.; Lucio, B.; González-Aguilar, J.; Romero, M. Macroencapsulation of Sodium Chloride as Phase Change Materials for Thermal Energy Storage. Sol. Energy 2018, 167, 1-9. [CrossRef]

115. Zheng, Y.; Barton, J.L.; Tuzla, K.; Chen, J.C.; Neti, S.; Oztekin, A.; Misiolek, W.Z. Experimental and Computational Study of Thermal Energy Storage with Encapsulated NaNO3 for High Temperature Applications. Sol. Energy 2015, 115, 180-194. [CrossRef]

116. Su, W.; Darkwa, J.; Kokogiannakis, G. Review of Solid-Liquid Phase Change Materials and Their Encapsulation Technologies. Renew. Sustain. Energy Rev. 2015, 48, 373-391. [CrossRef]

117. Pacio, J.; Fritsch, A.; Singer, C.; Uhlig, R. Liquid Metals as Efficient Coolants for High-Intensity Point-Focus Receivers: Implications to the Design and Performance of Next-Generation CSP Systems. Energy Procedia 2014, 49, 647-655. [CrossRef]

118. Fernández, A.I.; Barreneche, C.; Belusko, M.; Segarra, M.; Bruno, F.; Cabeza, L.F. Considerations for the Use of Metal Alloys as Phase Change Materials for High Temperature Applications. Sol. Energy Mater. Sol. Cells 2017, 171, 275-281. [CrossRef]

119. Pardo, P.; Deydier, A.; Anxionnaz-Minvielle, Z.; Rougé, S.; Cabassud, M.; Cognet, P. A Review on High Temperature Thermochemical Heat Energy Storage. Renew. Sustain. Energy Rev. 2014, 32, 591-610. [CrossRef]

120. Yadav, D.; Banerjee, R. A Review of Solar Thermochemical Processes. Renew. Sustain. Energy Rev. 2016, 54, 497-532. [CrossRef]

121. Prieto, C.; Cooper, P.; Fernández, A.I.; Cabeza, L.F. Review of Technology: Thermochemical Energy Storage for Concentrated Solar Power Plants. Renew. Sustain. Energy Rev. 2016, 60, 909-929. [CrossRef]

122. Müller, D.; Knoll, C.; Gravogl, G.; Artner, W.; Welch, J.M.; Eitenberger, E.; Friedbacher, G.; Schreiner, M.; Harasek, M.; Hradil, K.; et al. Tuning the Performance of $\mathrm{MgO}$ for Thermochemical Energy Storage by Dehydration—From Fundamentals to Phase Impurities. Appl. Energy 2019, 253, 113562. [CrossRef]

123. Müller, D.; Knoll, C.; Gravogl, G.; Jordan, C.; Eitenberger, E.; Friedbacher, G.; Artner, W.; Welch, J.M.; Werner, A.; Harasek, M.; et al. Medium-Temperature Thermochemical Energy Storage with Transition Metal Ammoniates-A Systematic Material Comparison. Appl. Energy 2021, 285, 116470. [CrossRef]

124. Romero, M.; Steinfeld, A. Concentrating Solar Thermal Power and Thermochemical Fuels. Energy Environ. Sci. 2012, 5, 9234-9245. [CrossRef]

125. André, L.; Abanades, S.; Flamant, G. Screening of Thermochemical Systems Based on Solid-Gas Reversible Reactions for High Temperature Solar Thermal Energy Storage. Renew. Sustain. Energy Rev. 2016, 64, 703-715. [CrossRef]

126. Silakhori, M.; Jafarian, M.; Arjomandi, M.; Nathan, G.J. Thermogravimetric Analysis of $\mathrm{Cu}, \mathrm{Mn}, \mathrm{Co}$, and Pb Oxides for Thermochemical Energy Storage. J. Energy Storage 2019, 23, 138-147. [CrossRef]

127. André, L.; Abanades, S. Recent Advances in Thermochemical Energy Storage via Solid-Gas Reversible Reactions at High Temperature. Energies 2020, 13, 5859. [CrossRef]

128. Makhanya, N.; Oboirien, B.; Ren, J.; Musyoka, N.; Sciacovelli, A. Recent Advances on Thermal Energy Storage Using MetalOrganic Frameworks (MOFs). J. Energy Storage 2021, 34, 102179. [CrossRef]

129. Wu, M.; Li, M.; Xu, C.; He, Y.; Tao, W. The Impact of Concrete Structure on the Thermal Performance of the Dual-Media Thermocline Thermal Storage Tank Using Concrete as the Solid Medium. Appl. Energy 2014, 113, 1363-1371. [CrossRef]

130. Stutz, B.; Le Pierres, N.; Kuznik, F.; Johannes, K.; Palomo Del Barrio, E.; Bédécarrats, J.-P.; Gibout, S.; Marty, P.; Zalewski, L.; Soto, J.; et al. Storage of Thermal Solar Energy. Comptes Rendus Phys. 2017, 18, 401-414. [CrossRef]

131. Rahbar, K.; Mahmoud, S.; Al-Dadah, R.K.; Moazami, N.; Mirhadizadeh, S.A. Review of Organic Rankine Cycle for Small-Scale Applications. Energy Convers. Manag. 2017, 134, 135-155. [CrossRef]

132. Kribus, A. A High-Efficiency Triple Cycle for Solar Power Generation. Sol. Energy 2002, 72, 1-11. [CrossRef]

133. Pramanik, S.; Ravikrishna, R.V. A Review of Concentrated Solar Power Hybrid Technologies. Appl. Therm. Eng. 2017, 127, 602-637. [CrossRef]

134. Powell, K.M.; Rashid, K.; Ellingwood, K.; Tuttle, J.; Iverson, B.D. Hybrid Concentrated Solar Thermal Power Systems: A Review. Renew. Sustain. Energy Rev. 2017, 80, 215-237. [CrossRef]

135. Soares, J.; Oliveira, A.C. Numerical Simulation of a Hybrid Concentrated Solar Power/Biomass Mini Power Plant. Appl. Therm. Eng. 2017, 111, 1378-1386. [CrossRef]

136. Bai, Z.; Liu, Q.; Lei, J.; Wang, X.; Sun, J.; Jin, H. Thermodynamic Evaluation of a Novel Solar-Biomass Hybrid Power Generation System. Energy Convers. Manag. 2017, 142, 296-306. [CrossRef]

137. Peterseim, J.H.; Tadros, A.; Hellwig, U.; White, S. Increasing the Efficiency of Parabolic Trough Plants Using Thermal Oil through External Superheating with Biomass. Energy Convers. Manag. 2014, 77, 784-793. [CrossRef]

138. Oyekale, J.; Heberle, F.; Petrollese, M.; Brüggemann, D.; Cau, G. Biomass Retrofit for Existing Solar Organic Rankine Cycle Power Plants: Conceptual Hybridization Strategy and Techno-Economic Assessment. Energy Convers. Manag. 2019, 196, 831-845. [CrossRef] 
139. Arnaoutakis, G.; Hellenic Mediterranean University. Concentrating Solar Power by Combined Tower and Parabolic trough Technology. In preparation. 2021.

140. Liu, H.; Zhai, R.; Patchigolla, K.; Turner, P.; Yang, Y. Off-Design Thermodynamic Performances of a Combined Solar Tower and Parabolic Trough Aided Coal-Fired Power Plant. Appl. Therm. Eng. 2021, 183, 116199. [CrossRef]

141. Corona, B.; de la Rúa, C.; San Miguel, G. Socio-Economic and Environmental Effects of Concentrated Solar Power in Spain: A Multiregional Input Output Analysis. Sol. Energy Mater. Sol. Cells 2016, 156, 112-121. [CrossRef]

142. Wagner, M.J.; Hamilton, W.T.; Newman, A.; Dent, J.; Diep, C.; Braun, R. Optimizing Dispatch for a Concentrated Solar Power Tower. Sol. Energy 2018, 174, 1198-1211. [CrossRef]

143. Llamas, J.M.; Bullejos, D.; Ruiz de Adana, M. Optimal Operation Strategies into Deregulated Markets for 50 MWe Parabolic Trough Solar Thermal Power Plants with Thermal Storage. Energies 2019, 12, 935. [CrossRef]

144. San Miguel, G.; Corona, B. Economic Viability of Concentrated Solar Power under Different Regulatory Frameworks in Spain. Renew. Sustain. Energy Rev. 2018, 91, 205-218. [CrossRef]

145. IEA. Evolution of Solar PV Module Cost by Data Source, 1970-2020—Charts—Data \& Statistics. Available online: https://www. iea.org/data-and-statistics / charts / evolution-of-solar-pv-module-cost-by-data-source-1970-2020 (accessed on 2 September 2021).

146. Photovoltaics Report-Fraunhofer ISE. Available online: http://www.ise.fraunhofer.de/en/publications/studies/photovoltaicsreport.html (accessed on 28 September 2021).

147. Martín-Martínez, S.; Cañas-Carretón, M.; Honrubia-Escribano, A.; Gómez-Lázaro, E. Performance Evaluation of Large Solar Photovoltaic Power Plants in Spain. Energy Convers. Manag. 2019, 183, 515-528. [CrossRef]

148. Tang, N.; Zhang, Y.; Niu, Y.; Du, X. Solar Energy Curtailment in China: Status Quo, Reasons and Solutions. Renew. Sustain. Energy Rev. 2018, 97, 509-528. [CrossRef]

149. Liu, H.; Zhai, R.; Fu, J.; Wang, Y.; Yang, Y. Optimization Study of Thermal-Storage PV-CSP Integrated System Based on GA-PSO Algorithm. Sol. Energy 2019, 184, 391-409. [CrossRef]

150. Gordon, J.M.; Fasquelle, T.; Nadal, E.; Vossier, A. Providing Large-Scale Electricity Demand with Photovoltaics and Molten-Salt Storage. Renew. Sustain. Energy Rev. 2021, 135, 110261. [CrossRef] 